University of Louisville

ThinkIR: The University of Louisville's Institutional Repository

Electronic Theses and Dissertations

$12-2004$

\title{
The role of nuclear factors of activated T-cells (NFAT) in neuronal death.
}

Agata M. Habas 1976-

University of Louisville

Follow this and additional works at: https://ir.library.louisville.edu/etd

\section{Recommended Citation}

Habas, Agata M. 1976-, "The role of nuclear factors of activated T-cells (NFAT) in neuronal death." (2004). Electronic Theses and Dissertations. Paper 555.

https://doi.org/10.18297/etd/555

This Master's Thesis is brought to you for free and open access by ThinkIR: The University of Louisville's Institutional Repository. It has been accepted for inclusion in Electronic Theses and Dissertations by an authorized administrator of ThinkIR: The University of Louisville's Institutional Repository. This title appears here courtesy of the author, who has retained all other copyrights. For more information, please contact thinkir@louisville.edu. 
THE ROLE OF NUCLEAR FACTORS OF ACTIVATED T-CELLS (NFAT) IN NEURONAL DEATH

\author{
$\mathrm{By}$ \\ Agata M. Habas \\ M.S., Agricultural University of Warsaw, 2001
}

\begin{abstract}
A Thesis
Submitted to the Faculty of the Graduate School of the University of Louisville in Partial Fulfillment of the Requirements for the Degree of
\end{abstract}

Master of Science

Department of Pharmacology and Toxicology University of Louisville

Louisville, Kentucky

December 2004 
THE ROLE OF NUCLEAR FACTORS OF ACTIVATED T-CELLS (NFAT) IN NEURONAL DEATH

Submitted by

Agata M. Habas

A Thesis Approved on

November 29, 2004

(Date)

by the Following Reading and Examination Committee:

Michal Hetman, Thesis Director

Evelyne Gozal

Theo Hagg

William Pierce

Scott Whittemore 


\section{ACKNOWLEDGEMENTS}

I gratefully acknowledge and thank Dr. Michal Hetman for his leadership throughout this project. I thank members of my reading committee: Drs. Evelyne Gozal, Theo Hagg, William Pierce and Scott Whittemore. I would also like to thank my husband for his tolerance and moral support during my academic career. Finally, I thank all my lab colleagues for nice atmosphere at work. 


\begin{abstract}
The Role of Nuclear Factors of Activated T-cells (NFAT) in Neuronal Death

Agata M. Habas
\end{abstract}

November 29, 2004

Nuclear Factor of Activated T-cells (NFAT) is a calcium-responsive transcription factor that orchestrates immune response and cardiovascular development. NFAT is also present in neurons and glia from the Central Nervous System (CNS) where it participates in calcium signaling. In physiological conditions, neuronal NFAT may contribute to the plasticity-related transcriptional regulation. On the other hand, excessive activation of calcium signaling and the subsequent overactivation of NFAT may contribute to neuronal death. To explore the possibility of NFAT-involvement in neuronal death I have determined which components of NFAT signaling are expressed in cultured rat hippocampal or cortical neurons. I found the presence of mRNAs for NFATc1, c3, c4 and c5. I also found that in primary neurons, NFAT transcriptional activity is increased by $\mathrm{KCl}$-mediated depolarization or by chemical trophic deprivation induced by a PI3K/Akt signaling inhibitor LY294002. This transcriptional activity may be blocked by calcineurin inhibitors: cyclosporin A and FK506 and ERK1/2 pathway inhibitor, U0126. Interestingly, overexpression of NFATc4 potentiated apoptotsis induced by trophic deprivation in cortical neurons. In summary, these data support the idea that excessive activation of NFAT may produce neuronal death following trophic deprivation. In future, I plan to study the mechanism of NFAT involvement in neuronal death. 


\section{TABLE OF CONTENTS}

PAGE

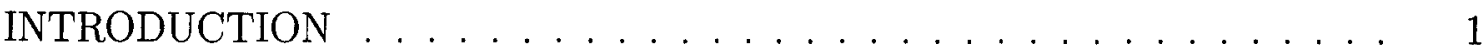

Damaging stimuli in the nervous system $\ldots \ldots \ldots \ldots$

The role of transcription factors in neuronal death . . . . . . . . . . 6

Nuclear Factors of Activated T-cells (NFAT) . . . . . . . . . . . 7

Possible involvement of NFAT in neuropathologies . . . . . . . . . . . . . 11

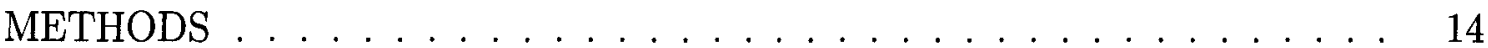

Plasmids . . . . . . . . . . . . . . . . . . . . . . . . 14

Drugs .............................. 14

Antibodies . . . . . . . . . . . . . . . . . . . . . . . . . 14

Cell culture . . . . . . . . . . . . . . . . . . . 15

RT-PCR assay . . . . . . . . . . . . . . . . . . . . 15

Transfection of neurons . . . . . . . . . . . . . . . . . 16

Immunostaining . . . . . . . . . . . . . . . . . 17

Reporter assay . . . . . . . . . . . . . . . . . . 17

Serum deprivation $\ldots \ldots \ldots \ldots \ldots \ldots$

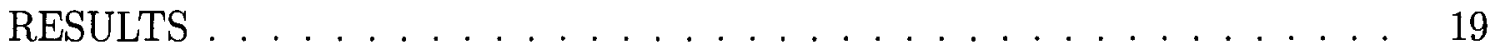

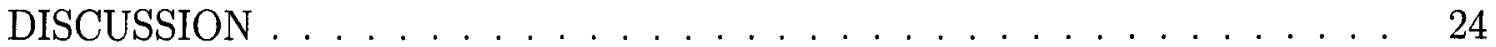

Future directions $\ldots \ldots \ldots \ldots$

REFERENCES . . . . . . . . . . . . . . . . . . . . 32

ABBREVIATIONS . . . . . . . . . . . . . . . . . . . . . . 43

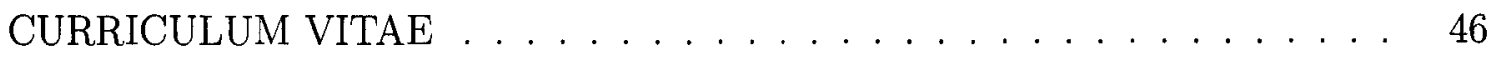




\section{LIST OF FIGURES}

FIGURE

PAGE

Figure 1. Regulation of homeostasis . . . . . . . . . . . . . 2

Figure 2. Various pathways of apoptosis . . . . . . . . . . . . . 4

Figure 3 . Activation of transcription by NFAT . . . . . . . . 8

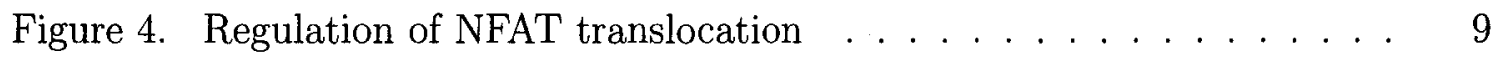

Figure 5. Overexpression of NFATc4 induces neuronal apoptosis . . . . . . 12

Figure 6. Inhibition of NFATc-driven transcription by NFATc4-delta reduces neuronal apoptosis induced by trophic deprivation . . . . . . . 13

Figure 7. Expression of NFAT family members in cultured neurons . . . . . 19

Figure 8. Calcineurin and MAPK pathways dependent activation of NFATmediated transcription in cortical neurons by $\mathrm{KCl} \ldots \ldots \ldots$

Figure 9. Translocation of NFATc . . . . . . . . . . . . . 21

Figure 10. Activation of NFATc4-mediated transcription by LY via calcineurin and MAPK pathways $\ldots \ldots \ldots \ldots \ldots \ldots \ldots$

Figure 11. NFATc4 wt magnifies cell death in cortical neurons after trophic

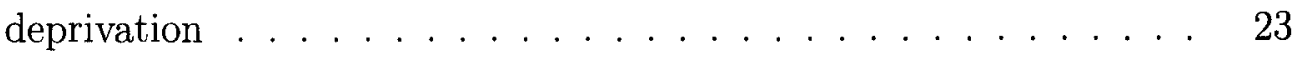

Figure 12. Activation of NFAT in cortical neurons . . . . . . . . . . . 28 


\section{LIST OF TABLES}

TABLE

PAGE

Table 1. Comparative features of necrosis and apoptosis $\ldots \ldots . . \ldots 3$

Table 2. List of NFAT proteins . . . . . . . . . . . . 7 


\section{CHAPTER I INTRODUCTION}

The cells of a multicellular organism are members of a highly organized community in which the number of cells is regulated by the proliferation or the rate of cell death. Mature neurons are non-proliferating cells so their number is regulated mostly by cell death. Neurons can undergo cellular suicide by a process known as programmed cell death or apoptosis. Cell death plays a very important role during development and also in adult organism. Mouse paws for example, are sculpted by cell death during embryonic development (Wood et al., 2000; Alberts et al., 2002). When a tadpole changes into a frog, the cells in the tail die, and the tail, which is not needed in the frog disappears (Wood et al., 2000; Alberts et al., 2002). In the developing nervous system, up to half or more of the nerve cells normally die soon after they are formed (Wood et al., 2000; Alberts et al., 2002). In this case, cell death adjusts the number of nerve cells to match the number of target cells that require innervation (Wood et al., 2000; Alberts et al., 2002). In adult tissues, cell death balances cell division (Alberts et al., 2002). If the physiological cell death is inhibited, cells normally destined to die, survive, leading to autoimmune conditions and cancer (Li and Yuan, 1999; Alberts et al., 2002). On the other hand, excessive cell death may contribute to several pathological conditions, including stroke and neurodegenerative diseases (Fig. 1) (Putcha and Johnson, 2004). Neurons may die in pathological conditions in diseases including Parkinson's disease, amyotrophic lateral sclerosis, retinitis pigmentosa, several forms of cerebellar degeneration, spinal muscular atrophy, and Alzheimer's disease (Hutchins and Barger, 1998; Sastry and Rao, 2000; Yuan et al., 2003). Several factors, such as oxidative stress, excitatory toxicity, inappropriate $\mathrm{Ca}^{2+}$ homeostasis, 
mitochondrial dysfunction, and lack of sufficient supply of neurotrophic factors, have been shown to contribute to cell death (Sastry and Rao, 2000).

\section{HOMEOSTASIS}

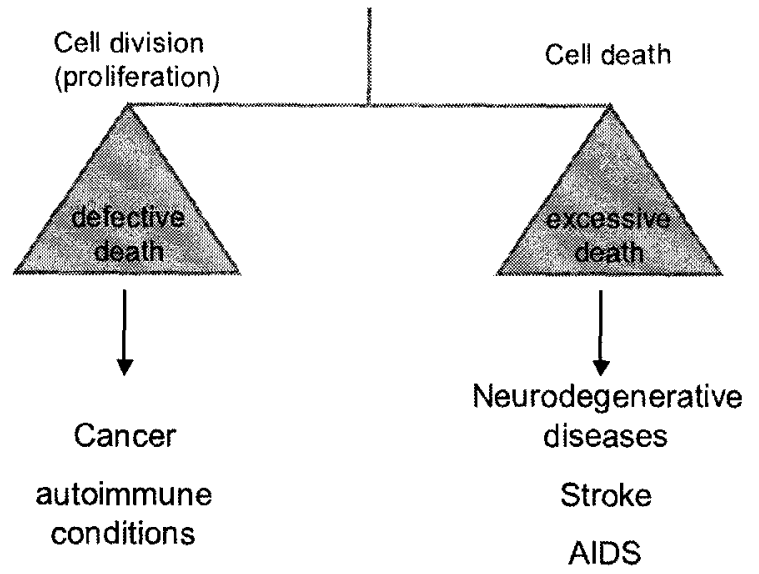

ALS

Figure 1. Regulation of homeostasis. Some diseases characterized by defective cell death (left) or excessive cell death (right).

Neuronal cell death may be divided into at least 2 types: apoptosis and necrosis (Petersen et al., 1999; Sastry and Rao, 2000; Habas et al., 2001). Necrosis is a passive process, mostly seen in pathologies and is generally pro-inflammatory (Raff et al., 1993; Habas et al., 2001; Kanduc et al., 2002). It is characterized by early swelling of intracellular organelles followed by swelling and loss of the plasma and nuclear membrane integrity (Petersen et al., 1999; Sastry and Rao, 2000). Apoptosis is a response to a specific pro-apoptotic signal or weak damage that involves specific biochemical events frequently including de novo gene expression in a dying cell (Raff et al., 1993; Vaux, 1993; Habas et al., 2001).

The characteristics of apoptosis include cytoplasmic condensation, nuclear pyknosis, chromatin condensation, DNA fragmentation, cell rounding, membrane blebbing, cytoskeletal collapse, and formation of membrane bound apoptotic bodies that are rapidly phagocytosed and digested by macrophages or neighboring cells (Sastry and Rao, 2000; Yuan et al., 2003) (Table 1). Apoptotic neuronal death may play an im- 
portant role in several pathologies in CNS. Defects in the control of apoptosis leading to excessive programmed cell death may contribute to stroke, ischemia, Traumatic Brain Injury (TBI), Alzheimer's Disease (AD), Parkinson's Disease (PD), Huntington's Disease (HD) (Choi, 1996; Ekshyyan and Aw, 2004; Gibson, 2001; Behl, 2000; Martin, 2001).

Apoptosis is a process that requires active cellular events (Pittman et al., 1993; Kanduc et al., 2002). Therefore, apoptosis takes longer to kill than the passive necrosis and may provide a better therapeutic window to perform neuro-protective manipulations (Kanduc et al., 2002).

Programmed cell death may be inhibited either by activation of anti-apoptotic or by inhibition of pro-apoptotic signaling pathway.

Table 1 Comparative features of necrosis and apoptosis (Sastry and Rao, 2000).

\begin{tabular}{ll}
\hline \multicolumn{1}{c}{ Necrosis } & \multicolumn{1}{c}{ Apoptosis } \\
\hline $\begin{array}{l}\text { Altered membrane permeability; } \\
\text { Potassium loss; sodium entry; } \\
\text { fall in membrane potential }\end{array}$ & Cytosol condensation \\
$\begin{array}{l}\text { Swelling of all cytoplasmic compart- } \\
\text { ments }\end{array}$ & Generally intact organelles \\
Destruction of mitochondria and other & $\begin{array}{l}\text { Protruberances from cell surface sepa- } \\
\text { organelles }\end{array}$ \\
$\begin{array}{l}\text { Depletion of cellular energy (ATP) } \\
\text { Lowered macromolecular synthesis }\end{array}$ & $\begin{array}{l}\text { No depletion of cellular energy } \\
\text { Macromolecular synthesis activation is } \\
\text { required }\end{array}$ \\
Affects tracts of contiguous cells & Affects scattered individual cells \\
Loose aggregates of chromatin & Highly condensed granular aggregates \\
& of chromatin \\
\hline
\end{tabular}

There are two major pathways leading to apoptotic death. They both employ activation of caspases and proteases. The first pathway can be initiated by DNA damage or trophic deprivation (TD). The death signal is sent through signaling molecules including $\mathrm{p} 53$ or JNK to mitochondria from where cytochrome $\mathrm{c}$ is released to the cytoplasm (Polster et al., 2004; Harada and Grant, 2003). The key regulators of cy- 
tochrome $\mathrm{c}$ release are proteins from $\mathrm{Bcl}-2$ family including anti-apoptotic members like Bcl-2, Bcl-Xl, Bag-1 and members that induce apoptosis: Bax, Bad and Bid. Cytochrome $\mathrm{c}$ leads to formation of an active complex composed of a protein Apaf-1 and a protease caspase- 9 . In this complex, caspase- 9 becomes active and stimulates other caspases including caspase-3, -6 and -7 that execute apoptosis (Fig. 2A) (Green and Reed, 1998; Robertson and Orrenius, 2000; Tsujimoto and Shimizu, 2000).

The second mechanism of programmed cell death includes pro-apoptotic signaling molecules known as death receptors such as p75 NGF receptor, TNFR1, Fas/CD95/ Apo-1, TRAIL (TNF-related apoptosis inducing ligands), DR4, and DR5 (Krammer, 2000; Nagane et al., 2000). After binding to their ligands, death receptors activate caspase 8 or 10 . This is followed by the activation of caspases $-3,-6$ and -7 (Fig. 2B). Therefore, in both apoptotic pathways, programmed cell death occurs via caspasemediated cleavage of multiple proteins leading to DNA fragmentation, destruction of cellular structures and formation of apoptotic bodies (Thornberry and Lazebnik, 1998; Tsujimoto and Shimizu, 2000; Habas et al., 2001).

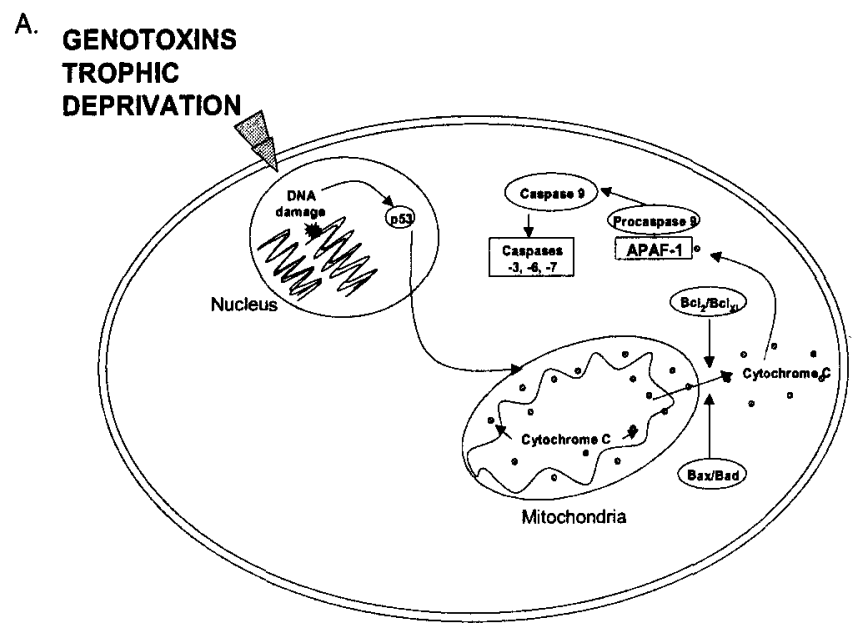

B.

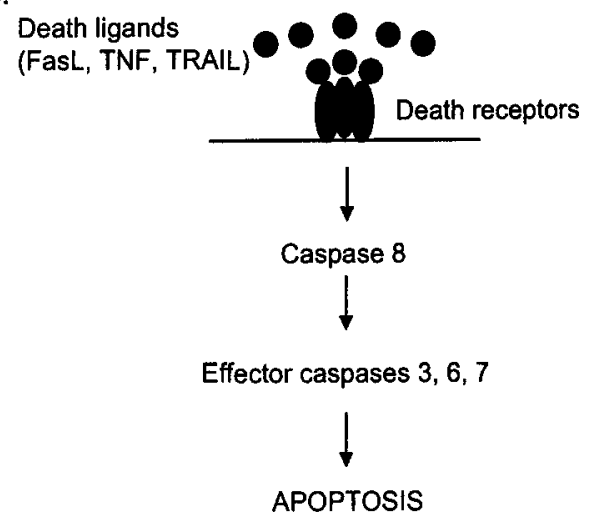

Figure 2. Various pathways of apoptosis. A. Mitochondrial pathway of apoptosis, B. Death receptor pathway of apoptosis.

In summary, programmed cell death is needed for the proper function of each organism. Apoptosis is an important factor in various diseases. Both increased or 
decreased apoptosis may result in pathologies. Therefore, identification of apoptotic regulation may provide new opportunities for therapies against such disorders as cancer or neurodegeneration.

\section{Damaging stimuli in the nervous system}

In the nervous system, various damaging stimuli activate signaling pathways that trigger cell death including apoptosis. Calcium influx, oxidative stress, DNA damage and TD are thought to be important cell death triggers in neurodegenerative diseases, traumatic injuries, stroke or ischemia (Simonian and Coyle, 1996; Mason et al., 1999; Petersen et al., 1999; Ghatan et al., 2000; Hugon et al., 2000; Lewen et al., 2001; Mattson, 2003).

It is known that intracellular $\mathrm{Ca}^{2+}$ overload can trigger either necrotic or apoptotic cell death (Orrenius and Nicotera, 1994; Vajda, 2002). Development of strategies that will block apoptotic and non-apoptotic death induced by $\mathrm{Ca}^{2+}$ influx is important as it may lead to the effective neuroprotection. Several effects of $\mathrm{Ca}^{2+}$ are mediated by $\mathrm{Ca}^{2+}$-binding proteins (e.g. calmodulin or calcineurin) (Orrenius and Nicotera, 1994). Cell death caused by calcium overload may be induced by the excessive stimulation of glutamate receptors. Two classes of glutamate receptors have been identified: (1) ionotropic glutamate receptors, which are ligand gated ion channels, and (2) metabotropic glutamate receptors, which are known as G-protein coupled receptors (Uings and Farrow, 2000). Excessive stimulation of the ion channels of N-methyl D-aspartate subtype of ionotropic glutamate receptors (NMDA receptors) leads to robust increase of $\mathrm{Ca}^{2+}$ load inside the cell and necrotic or apoptotic cell death (Orrenius and Nicotera, 1994; Vajda, 2002). On the other hand, moderate calcium influx through NMDA receptors plays a key role in neuronal development, survival and plasticity (Ghosh and Greenberg, 1995).

Neurons require the presence of survival factors to suppress cell death. Therefore, 
TD induces neuronal apoptosis, which in CNS may play a significant role in neurodegenerative diseases, fetal alcohol syndrome and neurotrauma (Hetman and Xia, 2000; McIntosh et al., 1998; Bhave et al., 1999). It may also play a role in cell death during development of the nervous system ( $\mathrm{Li}$ et al., 2001). A number of survival factors for neurons have been identified including serum, insulin like growth factor-1, neurotrophins and NMDA. These factors activate the phosphatidylinositol-3 kinase (PI3K) pathway, which use one of several signal transduction pathways implicated in the survival of neurons (Hetman and Xia, 2000). In primary neuronal culture, TD may be induced by serum withdrawal or by inhibition of PI3K pathway using its chemical inhibitor, LY294002 (Hetman and Xia, 2000).

\section{The role of transcription factors in neuronal death}

Apoptotic signaling in neurons leads to activation of killer gene expression that is mediated by several transcription factors like p53 or Forkhead box transcription factor, class 0 (FOXO) (Morrison and Kinoshita, 2000; Brunet et al., 2001). FOXO induces death receptors like Fas and FasL, or TRAIL (TNF-related apoptosis inducing ligands), Tumor Necrosis Factor-alpha (TNF $\alpha$ ) and its receptor (Brunet et al., 2001). Another transcription factor HIF (Hypoxia Inducible Factor) and p53, which are activated after oxidative stress, promote transactivation of pro-apoptotic bcl-2 family members leading to neuronal death (Halterman and Federoff, 1999). NFkB (Nuclear Factor $\mathrm{kB}$ ) is a transcription factor, which is activated in response to inflammation or oxidative stress. NFKB may serve a dual role in stimulating pathways that protect neuronal cells from death by activation of its target genes, Bcl-2 or Bcl-x and also in stimulating pathways that promote cell death by induction of TRAIL and other death receptors (Tamatani et al., 2000; Wajant, 2004). CCAAT enhancer binding proteins (c/EBPs) are transcription factors that play a role in cell survival in non-neuronal cells, while in neurons they promote death (Cortes-Canteli et al., 2002; 
Marshall et al., 2003). Nuclear Factor of Activated T-cells (NFAT) is a transcription factor that contributes to lymphocyte death. It does so by regulation of killer genes including FasL, Tumor Necrosis Factor-alpha (TNF $\alpha$ ), and cyclooxygenase-2 (Cox2) in lymphocytes (Lenzlinger et al., 2002; Humar et al., 2004). On the other hand, it is known that FasL, TNF $\alpha$ and Cox2 can induce neuronal death and their increased expression accompanies ischemia, TBI, stroke and some neurodegenerative diseases like AD or PD (Venters et al., 2000; Cernak et al., 2001; Facchinetti et al., 2002; Xiang et al., 2002). Therefore, it is possible that activation of NFAT contributes to neuronal loss that may play an important role in different neuronal diseases.

\section{Nuclear Factors of Activated T-cells (NFAT)}

NFAT is a family of transcription factors in which several members are activated in response to calcium. The NFAT signaling pathway was first described in lymphocytes as a pathway transducing signals from the polymorphic T-cell receptor to genes that coordinate an immune response (Graef et al., 2001). Several NFAT members are also necessary for the formation of the cardio-vascular system including morphogenesis of vertebrate heart valves. On the other hand, their pathological activation may produce cardiac hypertrophy (Graef et al., 2001; Crabtree and Olson, 2002).

Table 2 List of NFAT proteins (Hogan et al., 2003).

\begin{tabular}{lcc}
\hline Protein & Other names & Regulation \\
\hline NFATc1 & NFAT2, NFATc & $\mathrm{Ca}^{2+} /$ Calcineurin \\
NFATc2 & NFAT1, NFATp & $\mathrm{Ca}^{2+} /$ Calcineurin \\
NFATc3 & NFAT4, NFATx & $\mathrm{Ca}^{2+} /$ Calcineurin \\
NFATc4 & NFAT3 & $\mathrm{Ca}^{2+} /$ Calcineurin \\
NFATc5 & TonEBP & Osmotic stress \\
& & Integrin $(\alpha 6 \beta 4)$ activation \\
\hline
\end{tabular}

Five NFAT genes NFATc1-4 and NFATc5, have been identified (known also as 
NFAT1-4 and NFAT5; see table 2) (Bushdid et al., 2003; Hogan et al., 2003). The primordial family member is NFATc5, the only NFAT-related protein represented in the Drosophila genome. NFATc5 is identical to TonEBP (tonicity element binding protein), a transcription factor crucial for cellular responses to hypertonic stress (Fig. 3B) (Hogan et al., 2003). NFATc cytolasmic subunits require other transcription factors for DNA binding, including AP1, MEF2, GATA4 generally referred to as nuclear partners (NFATn) (Fig. 3A). The nuclear components of NFAT transcription complexes are often regulated by the protein kinase C (PKC) and Ras/MAPK (Mitogen-Activated Protein Kinase) pathways (Graef et al., 2003).

A.

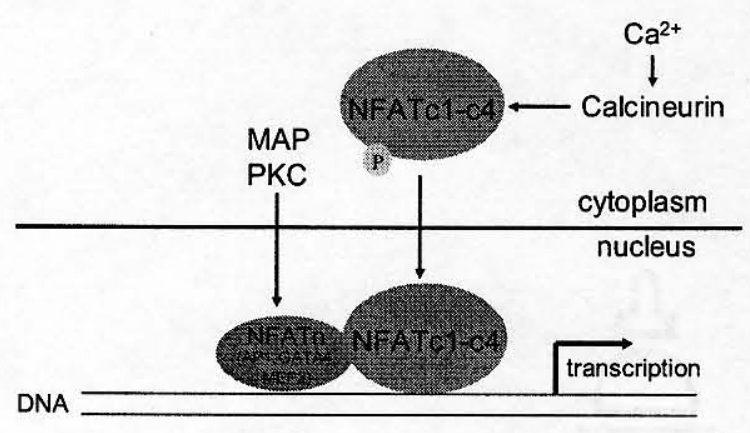

B.

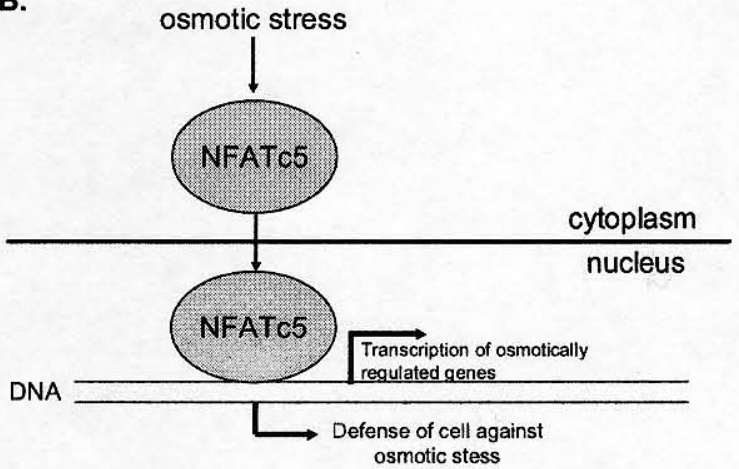

Figure 3. Activation of transcription by NFAT. A. NFATc1-c4 components are dephosphorylated and translocated to the nucleus where they bind to the DNA and induce several genes like IL2, IL3, IL4, IL5, IFN $\gamma$, TNF $\alpha$, FasL, CD40L, GM-CSF. To activate transcription, they require nuclear partners (NFATn) including AP1, GATA4 or MEF2. B. NFATc5 is activated and localized to the nucleus where it binds to the DNA and induces osmotically regulated genes.

NFATs contain both the nuclear localization sequence (NLS) and the nuclear export sequence (NES). (Okamura et al., 2000; Crabtree and Olson, 2002). Whether NLS or NES is masked depends on the phosphorylation state of specific serine residues in the regulatory domain (Crabtree and Olson, 2002; Hogan et al., 2003). Phosphorylation of these serine residues exposes NES whereas dephosphorylation exposes NLS (Crabtree and Olson, 2002; Hogan et al., 2003). In resting cells, the NLS of the cytoplasmic NFAT is masked due to phosphorylation on these serine residues. In 
stimulated cells, an increase of intracellular calcium ions activates $\mathrm{Ca}^{2+}$-dependent Ser/Thr phosphatase, calcineurin $(\mathrm{CaN})$, which then dephosphorylates the masking residues. Consequently, NLS is exposed and NFAT can be carried into the nucleus by the importin $\alpha / \beta$. Inside the nucleus, NFAT may be re-phosphorylated by protein kinases, including Ser/Thr kinase, Glyconen Synthase Kinase $3 \beta$ (GSK-3 $\beta$ ), Thr/Tyr (Threonin/Tyrosin) MAP kinases, p38, cAMP-dependent protein kinase (PKA) and Jun N-terminal kinase (JNK), exposing its NES and be exported by the exportin (Fig. 4) (Crabtree and Olson, 2002).

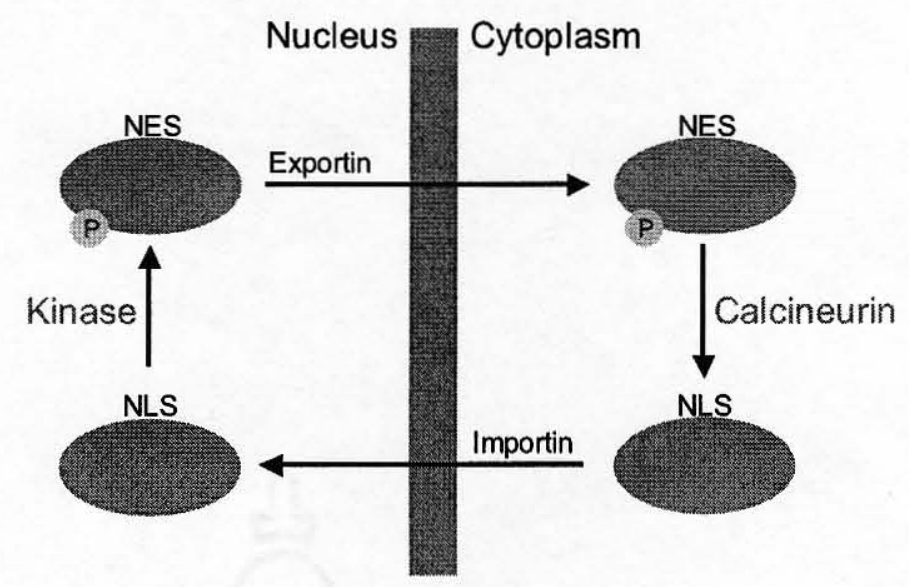

Figure 4. Regulation of NFAT translocation. NFATc1-c4 components are dephosphorylated by calcineurin and translocated to the nucleus by the importin; however, phosphorylation of NFAT by kinases activates its translocation to the cytoplasm by the exportin.

In resting T cells, NFAT is phosphorylated and localized in the cytoplasm. After cell stimulation, it is dephosphorylated by $\mathrm{CaN}$ and translocated to the nucleus where it binds to the DNA (Murphy and Hughes, 2002). It binds to promoter regions and induces expression of several genes including cytokines, such as interleukin (IL)2, IL3, IL4, IL5, IL8, IL13, granulocyte-macrophage colony-stimulating factor (GM-CSF), interferon (IFN)- $\gamma$, and tumor necrosis factor (TNF) $\alpha$, and cell surface receptors, such as CD40L, CTLA-4, and FasL (Masuda et al., 1998; Kiani et al., 2000; Humar et al., 2004). NFAT plays a critical role in the coordinate induction of expression of these genes (Masuda et al., 1998). 
NFATc5 has distinct characteristics from those of NFATc1-c4. First, the DNAbinding domain does not bind with Fos or Jun to form NFAT:AP1 heteromeric transcription factor. Second, NFATc5 lacks the conserved regulatory domains of the calcium-regulated NFATs and its subcellular distribution is not dependent on calcineurin (Macian et al., 2001). It has been reported that NFATc5 is responsible for cellular responses to osmotic stress. In osmotically-stressed cells, NFATc5 expression is increased and it is localized to the nucleus (Lopez-Rogriguez et al., 1999). Moreover, NFATc5 binding elements are present in the regulatory regions of a variety of osmotically-regulated genes including aldose reductase or sodium-myoinositol transporter (Macian et al., 2001).

NFAT family members were also found in astrocytes and hippocampal neurons (Graef et al., 1999; Graef et al., 2001; Jones et al., 2003). The activation of NFATdependent transcription in neurons requires $\mathrm{Ca}^{2+}$ influx via L-type voltage-sensitive calcium channel. Neuronal NFAT transcriptional complexes bind to inositol 1, 4, 5-triphosphate receptor, type 1 (IP3R1) promoter and are likely to be one of the transcription factors that regulate activity-dependent expression of this receptor during development (Graef et al., 2001). The role of NFAT in the central nervous system (CNS) is not well characterized. So far, it was shown that the NFATc4 isoform is involved in neurotrophin-mediated synaptic plasticity and memory formation (Graef et al., 1999; Groth and Mermelstein, 2003). Furthermore, it is known that neurotrophins and netrins stimulate calcineurin-dependent nuclear localization of NFATc4 and activation of NFAT-mediated gene transcription in cultured neurons leading to outgrowth of embryonic axons. Sensory and commissural neurons lacking calcineurin function or NFATc2, c3 and c4 are unable to respond to neurotrophins or netrin-1 with efficient axonal outgrowth (Graef et al., 2003). So far, the role of NFAT in neuronal survival is not known but it was shown that NFAT is involved in cell survival in cardiomyocytes (Pu et al., 2003). NFATc3 and NFATc4 are required for cardiac development and 
proper mitochondrial function (Bushdid et al., 2003). Moreover, NFAT transcription factors are involved in hypertrophy, but they are also critical survival factors that inhibit cardiomyocyte apoptosis induced by calcineurin activation ( $\mathrm{Pu}$ et al., 2003). It has been also shown that NFATc1 and NFATc2 are involved in cell death in lymphocytes (Humar et al., 2004; Cernal et al., 2001; Venters et al., 2000a; 2000b; Xiang et al., 2002). Moreover, NFAT is involved in activation of various killer genes including FasL, TNF $\alpha$ and Cox2, which cause death in neurons. Therefore, I decided to check whether NFAT is involved in neuronal apoptosis.

\section{Possible involvement of NFAT in neuropathologies}

Graef and co-workers reported that NFAT activity is present in neurons and is induced by calcium (Graef et al., 1999). So far, it was shown that NFAT is an important mediator of T-cell apoptosis (Linette et al., 1996; Srivastava et al., 1999). Moreover, Dr. Michal Hetman found that cortical neurons overexpressing NFATc4 undergo apoptosis (Fig. 5) while cells receiving a dominant negative mutant form of NFATc4 are partially protected from cell death induced by TD (Fig. 6) (unpublished observation). Consequently, I hypothesize that excessive NFAT activation may play a crucial role in neuronal death in neurological diseases. 
A.

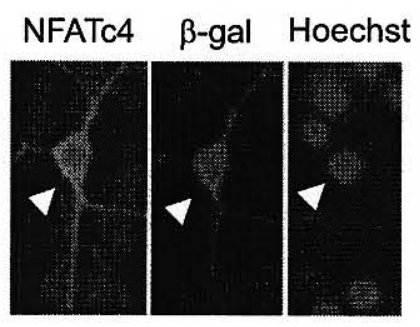

B.

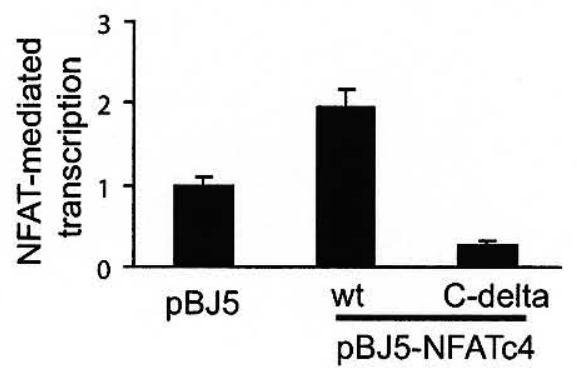

C. $\rightarrow-\mathrm{PBJ5}$

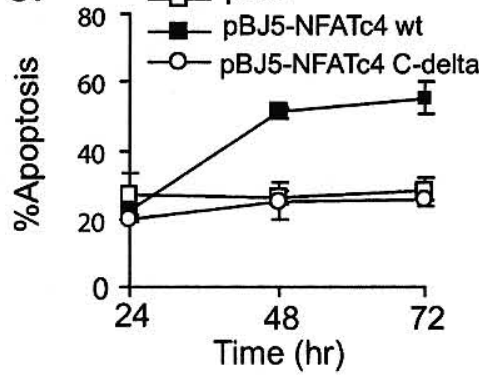

Figure 5. Overexpression of NFATc4 induces neuronal apoptosis. (A) Neurons were transfected for 48 hours with pBJ-NFATc4 $\mathrm{wt}$ and the $\beta$-galactosidase expression plasmid pON260 $(0.6 \mu \mathrm{g}+0.2 \mu \mathrm{g}$ of plasmid DNA/well). Expression of recombinant proteins was studied by immunostaining (green - HA epitope tag of NFATc4, red - $\beta$ galactosidase). Morphology in transfected cells was verified by staining with Hoechst 33258 . Transfected cells were identified by immunostaining for $\beta$-gal and Hoechst staining identified whether the cell was dead or alive. (B) NFAT-mediated transcription was assayed 48 hours after transfection of NFAT-Luc reporter $(0.12 \mu \mathrm{g} /$ well $)+$ pBJ5 empty cloning vector or wt NFATc4 or a dominant negative NFATc4 mutant, C-delta $(0.48 \mu \mathrm{g} /$ well). EF1LacZ was added to normalize for transfection efficiency. (C) Neurons were transfected using calcium phosphate method with pBJ5 empty cloning vector, pBJ5-NFATc4 wt or pBJ5-NFATc4Cdelta and co-transfected with $\beta$-galactosidase expression plasmid, pON260 $(0.4 \mu \mathrm{g}$ NFATc4 $+2 \mu \mathrm{g}$ pON260 of plasmid DNA/2 millions cells in a $35 \mathrm{~mm}$ dish). Neuronal apoptosis in transfected cells were identified by immunostaining for $\beta$-gal and by Hoechst 33258 staining. In (B) and (C) $n=3$ in triplicate determinations, the error bars are SEMs. 


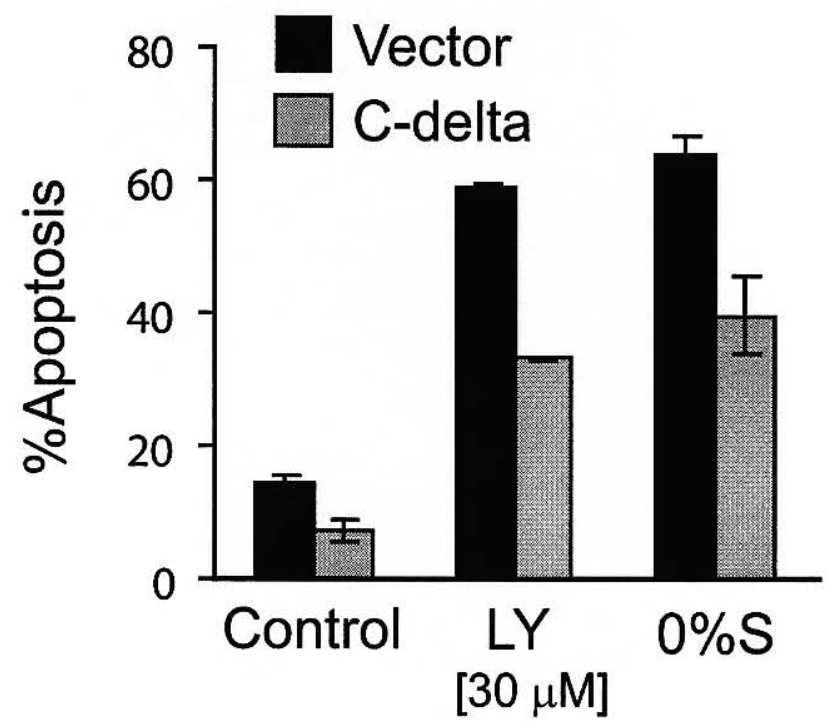

Figure 6. Inhibition of NFATc-driven transcription by NFATc4-delta reduces neuronal apoptosis induced by trophic deprivation. Neurons were transfected with NFAT-Luc reporter $(0.12 \mathrm{~g} /$ well $)+\mathrm{pBJ} 5$ empty cloning vector or a dominant negative pBJ5-NFATc4 mutant, C-delta $(0.48 \mathrm{~g} /$ well). EF1LacZ was added to normalize for transfection efficiency. Twenty four hour-apoptotic treatments were initiated 48 hours after transfection. LY, LY294002 $(30 \mu \mathrm{M}), 0 \% \mathrm{~S}$, medium without serum. Results for $n=2$ (duplicate determinations in 1 representative experiment), the error bars are SEMs.

To set the stage for further testing of this possibility, I studied expression of various NFATc family members in rat primary cortical and hippocampal neurons and characterized NFATc-mediated transcriptional response in these systems. 


\section{CHAPTER II \\ METHODS}

\section{Plasmids}

Dominant-negative mutant of NFATc4 was generated by Dr. Hetman through deletion of the C-terminal DNA binding domain starting at amino acid 439 of human cDNA for NFATc4. The mutant was then cloned N-terminally to the HA tag in pBJ5 mammalian expression vector. Expression plasmid for wt and constitutive active NFATc4 are described (Graef et al., 1999; Neal and Clipstone, 2003; Schubert et al., 2003). Expression plasmid for wt NFATc1 is described (Beals et al., 1997).

\section{Drugs}

Pharmacological agents that were used are commercially available and were dissolved using appropriate solvents. $\mathrm{KCl}\left(30 \mathrm{mM}\right.$; VWR) was dissolved in $\mathrm{H}_{2} \mathrm{O}$; LY294002 (30 $\mu \mathrm{M}$; Sigma) was dissolved in DMSO; CsA ( $1 \mu \mathrm{g} / \mathrm{ml}$; Bedford Laboratories) was dissolved in $0.9 \%$ sodium chloride; FK506 (200 ng/ml; A.G. Scientific, Inc.) was dissolved in DMSO; U0126 (40 $\mu$ M; Sigma) was dissolved in DMSO.

\section{Antibodies}

Anti- $\beta$ gal (1:500, rabbit; Calbiochem) and anti-HA (1:80, mouse; Novus biologicals) were used for immunostaining as primary antibodies. Texas Red-conjugated goat antibody to rabbit IgG (1:100; Calbiochem) or for double staining additional secondary antibody FITC-conjugated goat antibody to mouse IgG (1:100; Calbiochem), was 
used for immunostaining as secondary antibodies.

\section{Cell culture}

Primary culture of cortical and hippocampal neurons were prepared from newborn Sprague-Dawley rats according to the established protocols (Furshpan and Potter, 1989; Bading and Greenberg, 1991). Culture medium was Basal Medium Eagel (BME) supplemented with $10 \%$ heat-inactivated bovine calf serum (Hyclone, Logan, $\mathrm{Ut}$ ), $35 \mathrm{mM}$ glucose, $1 \mathrm{mM}$ L-glutamine, $100 \mathrm{U} / \mathrm{ml}$ of penicillin, $0.1 \mathrm{mg} / \mathrm{ml}$ streptomycin. Cytosine arabinoside (AraC) $(2.5 \mu \mathrm{M})$ was added to cultures on the second day after seeding (DIV 2) to inhibit the proliferation of non-neuronal cells. AraC at this concentration does not affect neuronal survival (Hetman et al., 1999). Cortical neurons were seeded in concentration of 2 million cells $/ 35 \mathrm{~mm}$ plate or 0.5 million cells/well on 24-well plate. Hippocampal neurons were seeded in concentration of 0.6 million of cells $/ 35 \mathrm{~mm}$ plate or 0.15 million of cells/well on 24 -well plate. Using this procedure, the cultures consist of about 80-90\% MAP-2 positive neurons and about $10 \%$ of GFAP positive astrocytic cells at DIV5 (Hetman et al., 1999a). All experiments were performed at in vitro days 6 or 7 , when the newborn-derived neurons are susceptible to oxidative stress, excitotoxicity, DNA damage agents or TD (Hetman et al., 1999; Hetman et al., 2002). Both cortex and hippocampus ensure enough cells to perform biochemical analysis such as promoter assays, western blots or electromobility shift assays.

\section{RT-PCR assay}

RNA for RT-PCR was isolated from neurons using the SV Total RNA Isolation Kit (Promega). cDNA synthesis was done using a AMV cDNA synthesis kit from Invitrogen. Primers, designed using OligoExplorer freeware from University of Koupio, 
as follows:

NFATc1 sense-aacgcctgaccaccgatag, asense-gctgccttccgtctcatagtg;

NFATc2 sense-ctgccagcttcatttctgacacct, asense-ttgagggcatccatgagaacagca;

NFATc3 sense-gtagagactgacatccctttg, asense-atctgtagatttattggcttttc;

NFATc4 sense-tgccaacattgactgtgctgga; asense-acaccactttagagtctggcagga;

NFATc5 sense-gccaaagcacctcactatg, asense-gcagggagttgtatttcg.

PCR was run using standard protocols and MJ Research thermal cycler. Reaction product was analyzed by agarose gel electrophoresis.

\section{Transfection of neurons}

Neurons were transfected using Lipofectamine 2000 reagent (Invitrogen) at DIV3-4 according to the established protocols (Hetman et al., 2002). Medium from 24-wells plates was collected and replaced by transfection media - Basal Medium Eagel (BME, BioWhittaker) supplemented with $35 \mathrm{mM}$ Glucose, $1 \mathrm{mM}$ L-glutamine, $100 \mathrm{U} / \mathrm{ml}$ of peniciline and $0.1 \mathrm{mg} / \mathrm{ml}$ streptomycine. Transfection mixture contained $100 \mu \mathrm{l}$ per well of BME, $0.6 \mu \mathrm{g}$ per well DNA and $1.5 \mu$ l lipofectamine 2000 per well (Invitrogen). First, $50 \mu \mathrm{l}$ of BME was mixed with lipofectamine in one eppendorf, another $50 \mu \mathrm{l}$ of BME was mixed with DNA in another eppendorf and then the two mixtures were mixed together and incubated 20-60 minutes in room temperature before adding to the cells. Cells were transfected with $100 \mu \mathrm{l}$ of transfection mixture per well and were incubated 2 hours at $37^{\circ} \mathrm{C}$ under a water saturated atmosphere of $95 \%$ ambient air and $6.5 \% \mathrm{CO}_{2}$. Transfection medium was then removed and replaced by conditioned medium collected from the cells 2 hours earlier that was supplemented with $1 \mathrm{~g} / \mathrm{ml}$ glucose and centrifuged in $1000 \mathrm{rpm}$ by 10 minutes in room temperature in order to get rid of dead cells. Cells transfected with plasmid conjugated with EGFP could be seen live or after fixation without immunostaining. 


\section{Immunostaining}

Cortical neurons plated on 24-wells plates were co-transfected using Lipofectamine 2000 (Invitrogen) with NFATc4 wt, with NFATc4 tagged with hemaglutinin (HA) or sr $\alpha$ together with pON260. Two days after transfection, cells were treated with drugs (LY294002, $30 \mu \mathrm{M}$ or serum deprivation) then fixed or untreated cells were fixed with 4\% para-formaldechyde in PBS. After washing with PBST (phosphate buffered saline - PBS, Triton 0.1\%), cells were permeabilized with $0.5 \%$ NP40 diluted in PBS for 30 minutes, then all unspecific sites were blocked with $2.5 \%$ BSA, $2.5 \%$ horse serum diluted in PBST overnight. Next, primary antibody, that was either anti- $\beta$ gal (1:500, rabbit) or anti-gal (1:500, rabbit) mixed with anti-HA (1:80, mouse), was added to the cells and was incubated for 2 hours in room temperature. Then, cells were washed 3 times with PBST and secondary antibody was added that was Texas Red-conjugated goat antibody to rabbit IgG (1:100) or for double staining additional secondary antibody FITC-conjugated goat antibody to mouse IgG (1:100) was used and cells were incubated with these antibodies 1 hour in room temperature. Then, cells were washed with PBST and additionally stained with Hoechst 33258 to visualize the nuclei.

\section{Reporter assay}

Cortical neurons plated on 24-well plates were transfected using Lipofectamine 2000 (Invitrogen) with $0.2 \mu \mathrm{g} /$ well NFATc-Luc (Graef et al., 1999) and $0.125 \mu \mathrm{g} /$ well EF1 $\alpha . L a c Z$ DNA for normalization of transfection efficiency. Two days after transfection, cells were treated with $30 \mathrm{mM} \mathrm{KCl}$ and incubated for 24 hours. Then, cells were lysed with $100 \mu \mathrm{l} /$ well of reporter lysis buffer (Promega) and activities of luciferase or $\beta$-galactosidase were measured as described using Orion II Luminometer and Promega reagents ( $\beta$-galactosidase Enzyme Assay System with Reporter Lysis Buffer and Luciferase Assay System). The reporter gene luciferase activity was nor- 
malized to $\beta$-galactosidase activity expressed as the fold induction relative to the control.

\section{Serum deprivation}

Serum deprivation was performed as described previously (Hetman et al., 1999). Briefly, cells were washed twice with serum-free BME and incubated in serum-free BME supplemented with $35 \mathrm{mM}$ glucose, $1 \mathrm{mM}$ L-glutamine, $100 \mathrm{U} / \mathrm{ml}$ penicillin, $0.1 \mathrm{mg} / \mathrm{ml}$ streptomycin, and $2.5 \mathrm{mM}$ cytosine arabinoside (all from Sigma). Control cells were washed similarly and then incubated for matched time points in serumcontaining conditioned medium. 


\section{CHAPTER III}

\section{RESULTS}

To identify which members of NFAT family are present in neurons, I performed RTPCR assay using NFAT-specific primers and cDNA from primary cortical or hippocampal neurons or from P1 brain. As a positive control, I used cDNA from newborn rat tissues including heart, spleen and thymus. It is known that in these tissues several NFATc family members are expressed. My results indicate that NFATc1, NFATc3, NFATc4 and NFATc5 are present in mRNAs isolated from cultured cortical and hippocampal neurons (Fig. 7).

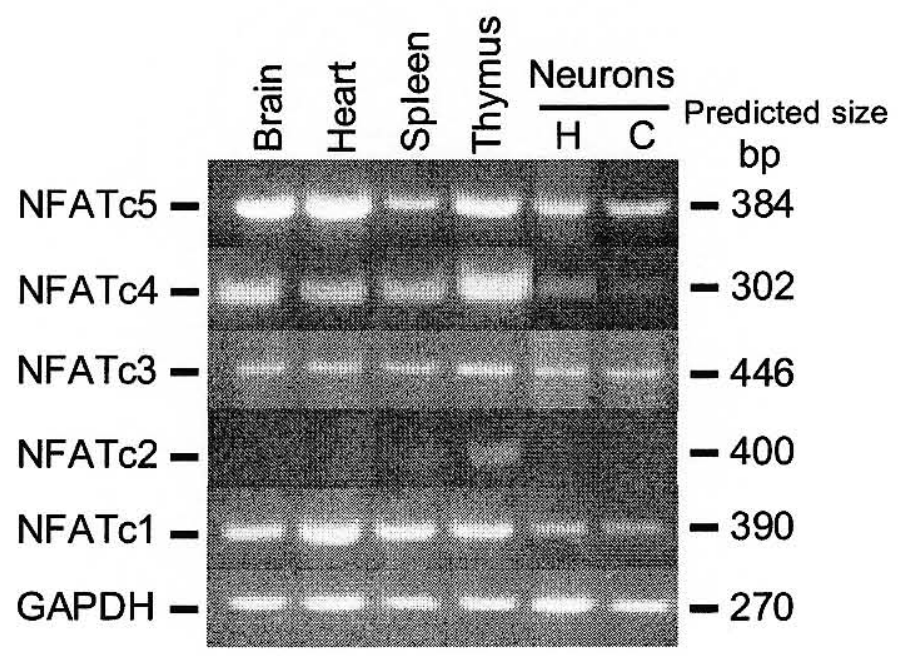

Figure 7. Expression of NFAT family members in cultured neurons. Half $\mu \mathrm{g}$ of DNAs and $2 \mu \mathrm{M}$ specific primers were used for each PCR reaction. For NFATc1 the number of cycles was 29, for NFATc2, NFATc3, NFATc4 and NFATc5 - 32 cycles. Equal amounts of template were further confirmed by PCR with GAPDH-specific primers. Tissues were isolated from newborn rats, neuronal cDNA was prepared from cells 6 days after plating (DIV6). PCR products were analyzed by agarose electrophoresis.

Then, I tested whether NFAT-mediated transcriptional activity is present in primary cortical neurons. I transfected cortical neurons with a plasmid construct that 
contains a luciferase reporter gene under control of an NFAT promoter. Three days after transfection, I stimulated cells for 20 hours with $30 \mathrm{mM} \mathrm{KCl}$. Luciferase activity in neurons transfected with the reporter was 2000 times higher than in untransfected cells. Interestingly, NFAT-mediated transcription was further stimulated with $\mathrm{KCl}$ exceeding the control values by 2.5 times. It suggests that NFAT activity is present in cortical neurons and is increased by calcium influx (Fig. 8A).

A.

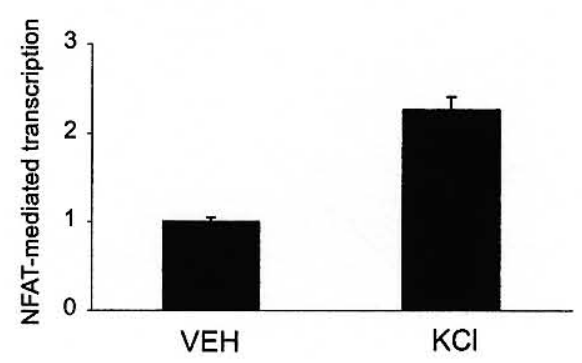

B.

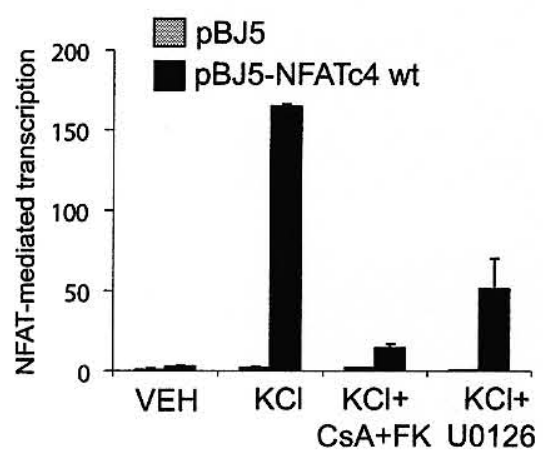

C.

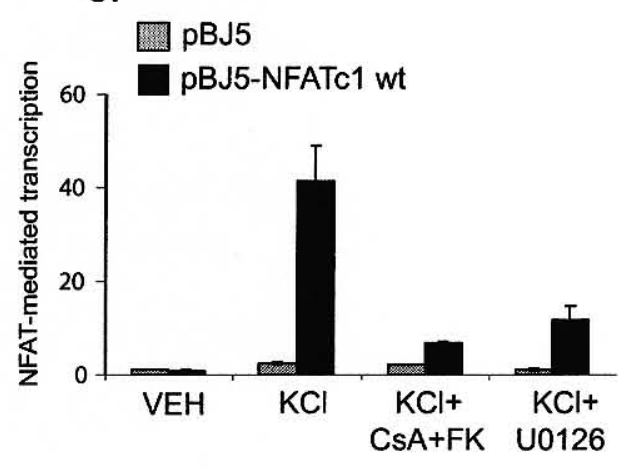

Figure 8. Calcineurin and MAPK pathways dependent activation of NFATmediated transcription in cortical neurons by $\mathrm{KCl}$. (A) Cells were transfected with NFAT-Luc reporter $(0.2 \mu \mathrm{g}$ plasmid DNA/well in a 24-well plate) and EF1lacZ plasmid $(0.125 \mu \mathrm{g}$ plasmid DNA/well). Three days after transfection, cells were treated with $30 \mathrm{mM}$ $\mathrm{KCl}$ for $24 \mathrm{~h}$. Neurons were lysed and luciferase activity was measured. (B), (C) Cells were transfected in (C) with pBJ5-NFATc1 wt $(0.1 \mu \mathrm{g}$ plasmid DNA/well) or in (B) with pBJ5NFATc4 wt $(0.1 \mu \mathrm{g}$ plasmid DNA/well) and with NFAT-Luc $(0.2 \mu \mathrm{g}$ plasmid DNA/well $)$ reporter and EF1lacZ $(0.125 \mu \mathrm{g}$ plasmid DNA/well) plasmid to normalize for transfection efficiency. After $72 \mathrm{~h}$ cells were pretreated with cyclosporin A, CsA $(1 \mu \mathrm{g} / \mathrm{ml})$ and FK506, FK $(0.2 \mu \mathrm{g} / \mathrm{ml})$ or with U0126 $(40 \mu \mathrm{M})$ for $30 \mathrm{~min}$. and then were treated with $25 \mathrm{mM} \mathrm{KCl}$. After another $20 \mathrm{~h}$, cells were lysed and luciferase activity was determined. In (A) $n=3$ (triplicate determinations in 1 representative experiment), in (B) and (C) $n=6$ (triplicate determinations from 2 representative experiments), the error bars are SEMs. 
Next, I overexpressed pBJ5-NFATc4 wt or pBJ5-NFATc1 wt isoforms in cortical neurons. The transfection efficiency using Lipofectamine ranged from 0.1 to $10 \%$ of neurons. Three days after transfection, I stimulated cells with $25 \mathrm{mM} \mathrm{KCl}$ in the presence or absence of calcineurin's inhibitors: Cyclosporin A (CsA) and FK506 (FK) or MAPK pathway blocker, U0126. I noticed that after overexpression of NFATc4 wt, NFAT-mediated transcription was increased above 150 times by KCl. Similarly, after overexpression of NFATc1 wt, $\mathrm{KCl}$ induced NFAT-mediated transcription, which was increased above 40 times. Interestingly, this phenomenon was blocked in both cases by calcineurin inhibitors and by MAPK pathway inhibitor (Fig. $8 \mathrm{~B}$ and $8 \mathrm{C}$ ). These data suggest that in cortical neurons, both calcineurin and MAPK pathways are involved in $\mathrm{KCl}$ response activating NFAT-mediated transcription.

It is known that in non-neuronal cells, activation of NFAT is regulated by $\mathrm{Ca}^{2+}$ influx leading to translocation of NFAT from the cytoplasm to the nucleus where it activates gene transcription. To test this phenomenonon, I transfected cells with pNFATc4 EGFP fusion protein and stimulated cells with $25 \mathrm{mM} \mathrm{KCl}$ two days after transfection. My data indicate that in the absence of $\mathrm{KCl}$, NFATc was present in pericarial cytosol and in the processes. In the presence of $\mathrm{KCl}$, NFATc was translocated to the nucleus (Fig. 9). These data show that NFAT can be translocated to the nucleus upon $\mathrm{Ca}^{2+}$ influx.

\section{$25 \mathrm{mM} \mathrm{KCl}$}
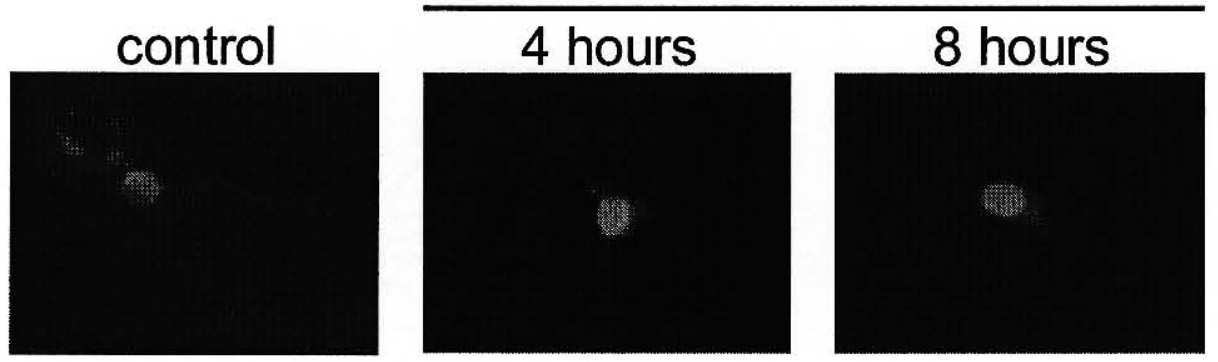

Figure 9. Translocation of NFATc. Cortical neurons were transfected with pNFATc4EGFP and 48 hours later were treated with $25 \mathrm{mM} \mathrm{KCl}$. Green staining indicates localization of NFATc4-EGFP fusion protein that is translocated to the nucleus after $\mathrm{KCl}$ treatment. 
To check if proapoptotic stimulation with LY294002, which is a chemical inhibitor of the main trophic support signaling pathway, phospatidylinositol-3-kinase (PI3K) can increase NFAT driven transcription, cortical neurons were co-transfected with NFATLuc reporter, pBJ5NFATc4 wt and EF1lacZ. Three days after transfection, cells were treated with LY294002 in the presence or absence of calcineurin's inhibitors, CsA and FK or MAPK pathway blocker, U0126. Cells treated with vehicle were used as a control. LY294002 induced almost 10-fold increase in NFAT-mediated transcription, which was blocked by CsA + FK and by U0126 (Fig. 10). These results suggest that NFATc4-mediated transcription is activated by the inhibitor of PI3K via calcineurin and MAPK pathways.

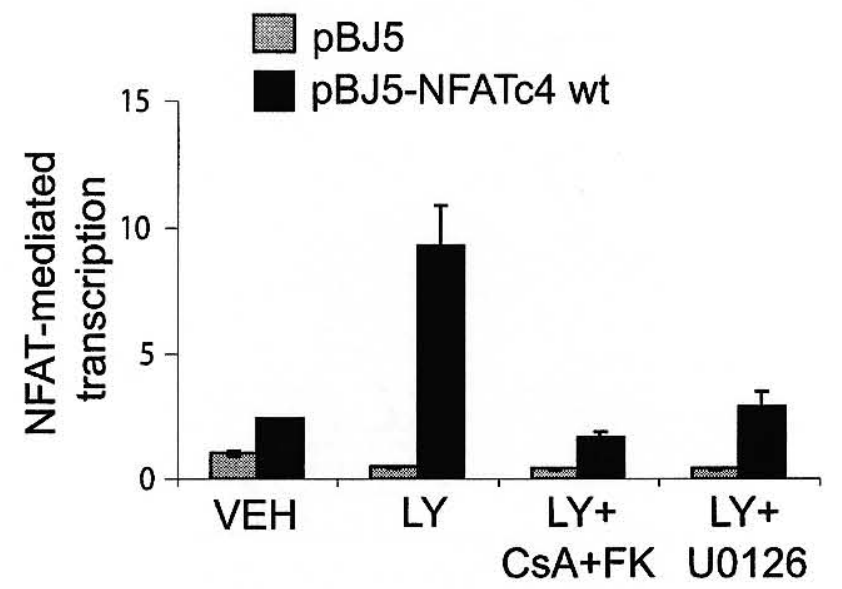

Figure 10. Activation of NFATc4-mediated transcription by LY via calcineurin and MAPK pathways. Cells were transfected with pBJ5-NFATc4 wt $(0.1 \mathrm{mg}$ plasmid DNA/well) and with NFAT-Luc (0.2 mg plasmid DNA/well) reporter and EF1lacZ $(0.125 \mathrm{mg}$ plasmid DNA/well) plasmid to normalize for transfection efficiency. After $72 \mathrm{~h}$, cells were pretreated with cyclosporin A, CsA $(1 \mathrm{mg} / \mathrm{ml})$ and FK506, FK $(0.2 \mathrm{mg} / \mathrm{ml})$ or with U0126 (40 mM) for $30 \mathrm{~min}$. and then were treated with inhibitor of PI3K, LY294002 $(30 \mathrm{mM})$. After $20 \mathrm{~h}$, cells were lysed and luciferase activity was determined. Results for $n=3$ (triplicate determinations in 1 representative experiment), the error bars are SEMs.

In order to test a possible NFAT involvement in apoptosis, I co-transfected cortical neurons with NFATc4 wt or empty vector $(\operatorname{sr} \alpha)$ in the presence of $\beta$-galactosidase expression plasmid that was a marker for the transfection. Two days after transfection, apoptosis was induced by serum deprivation and LY294002 treatment. After 24 hours 
of incubation, cells were fixed and immunostaining were performed. The number of transfected apoptotic cells was scored (Fig. 11). Expression of NFATc4 wt was visible in cortical neurons after immunostaining. Data show that expression of NFATc4 wt was sufficient to enhance neuronal death induced by both serum deprivation and LY294002 treatment from $20-25$ to $40 \%$.
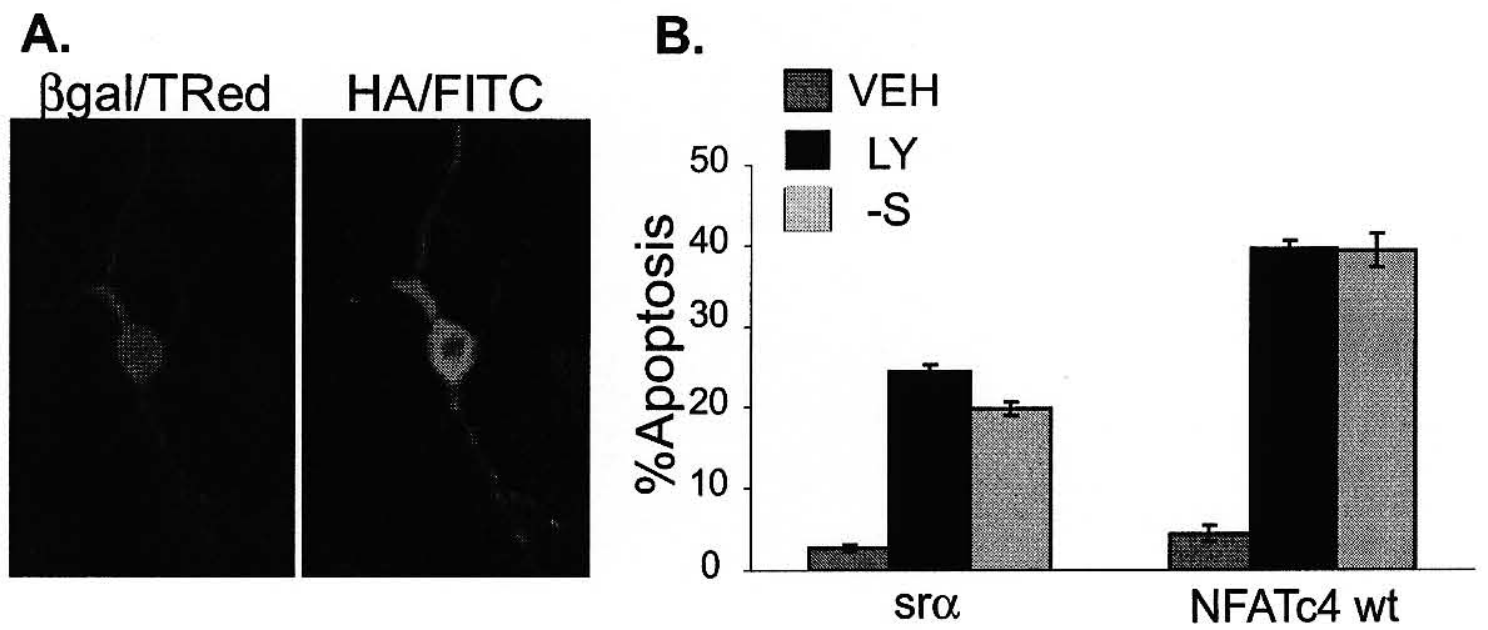

Figure 11. NFATc4 wt magnifies cell death in cortical neurons after trophic deprivation. (A) Neurons were transfected for 48 hours with pBJ-NFATc4 wt and the $\beta$-galactosidase expression plasmid, pON260 $(0.6 \mu \mathrm{g}+0.2 \mu \mathrm{g}$ of plasmid DNA/well). Expression of recombinant proteins was studied by immunostaining (green - HA epitope tag of NFATc4, red - $\beta$-galactosidase). Morphology in transfected cells was verified by staining with Hoechst 33258. Transfected cells were identified by immunostaining for $\beta$-gal and Hoechst staining identified whether the cell was dead or alive. (B) Cortical neurons were transfected with empty vector, $\operatorname{Sr} \alpha(0.4 \mu \mathrm{g}$ of DNA/well), pBJ-NFATc4 dominant negative mutant or pBJ-NFATc4 wt $(0.2 \mu \mathrm{g}$ of plasmid DNA/well) and the $\beta$-galactosidase expression plasmid, pON260 (0.2 $\mathrm{g}$ DNA/well). Two days after transfection, cells were treated with serum deprivation or LY294002. The effectiveness of transfection was studied by immunostaining with $\beta$-galactosidase. The morphology of transfected cells was verified by staining with Hoechst 33258. The number of dead cells as counted using a microscope. Results for $n=3$ (triplicate determinations in 1 representative experiment), the error bars are SEMs.

In summary, my data suggest that NFAT is present in primary neuronal cultures. Moreover, its transcriptional activity is induced by calcium influx or TD. In both cases, calcineurin and MAPK pathways are required for the activation. Furthermore, overexpression of NFATc4 wt enhances apoptosis induced by TD in neuronal culture. 


\section{CHAPTER IV}

\section{DISCUSSION}

I found that several members of the NFATc family are expressed in postnatal hippocampal and cortical neuronal cultures. Furthermore, I demonstrated that NFAT could mediate transcription response in these cells following $\mathrm{KCl}$ stimulation. I also found that, in $\mathrm{KCl}$ treated cells, calcineurin and MAPK pathways were required for NFAT-driven transcription and that it was accompanied by NFATc translocation to the nucleus. Interestingly, I observed activation of NFAT-mediated transcription following LY294002 treatment. This activation may involve calcineurin and MAPK pathways. In addition, LY294002 treatment or TD induced more apoptosis in cortical neurons that overexpressed NFATc4 wt. Therefore, I propose that in neurons, NFAT may be involved in TD-induced apoptosis.

Using RT-PCR, the expression of NFATc1, NFATc3, NFATc4 and NFATc5 was found in primary cortical and hippocampal neurons. So far, NFATc expression was shown in non-neuronal cells including lymphocytes, natural killer cells and astrocytes (Lyakh et al., 1997; Viola et al., 1998; Jones et al., 2003). In hippocamal neurons, expression of only one NFATc isoform, NFATc4, has been reported (Graef et al., 1999). My data suggest that it is also present in cortical neurons. Expression of other NFATc isoforms including NFATc1, NFATc3 and NFATc5 in neurons is described for the first time in this thesis. Cortical and hippocampal neurons are not pure neuronal cultures. These cultures may also contain astrocytes. The culture protocol procedure that was used in this research was reported to result in primary cortical cultures consisting of $90 \%$ of neurons and $10 \%$ astrocytes (Hetman et al., 1999). Therefore, immunocytochemistry or in situ hybridization is needed to confirm that 
NFATc1, c3, c4 and c5 are indeed expressed in neurons. NFATc2, which was not expressed in neurons, may play an important role in other cell types. For example, in lymphocytes, its expression leads to cell death (Peng et al., 2001). However, lack of NFATc2 expression in neurons suggests that other NFATc isoforms are responsible for the role that NFATc2 plays in other cell types. It suggests that NFATc isoforms may activate different genes in various cell types.

Importantly, the various isoforms of NFAT family may mediate diverse responses in the CNS as NFATc1 and NFATc3 are regulated by $\mathrm{Ca}^{2+} /$ calcineurin pathway while NFATc5 is regulated by osmotic stress (Hogan et al., 2003). My data indicate that non-toxic, membrane depolarizing concentration of $\mathrm{KCl}$ activated endogenous NFAT in cortical neurons. Moreover, NFAT-mediated transcriptional activity was induced by $\mathrm{KCl}$ in cells overexpressing NFATc1 wt and NFATc4 wt. Inhibition of calcineurin or MAPK pathways blocked the induction. Similarly, NFAT activation by $\mathrm{KCl}$ that required calcineurin has been shown previously in hippocampal neurons and that $\mathrm{K}^{+}$depolarization acts specifically through L-type $\mathrm{Ca}^{2+}$ channels (Graef et al., 1999). My data show that $\mathrm{KCl}$ induced NFAT-dependent transcription was not blocked by inhibition of NMDA receptors, which are another major $\mathrm{Ca}^{2+}$ channel in neurons (data not shown). Therefore, in cortical neurons, activation of NFATmediated transcription by calcium influx is likely mediated by L-type $\mathrm{Ca}^{2+}$ channels.

It is known that Ras/MAPK pathway is activated after membrane depolarization, which leads to calcium influx through L-type $\mathrm{Ca}^{2+}$ channels in PC12 cell lines, in cortical primary cultured neurons and in cerebellar granule neurons (Bading and Greenberg, 1991; Rosen et al., 1994; Borodinsky and Fiszman, 1998). My data show inhibition of NFAT-mediated transcription activity after blocking the ERK1/2 pathway. Therefore, it suggests that ERK1/2 participates in NFAT activation by calcium influx. In many cell types including lymphocytes or cardiomyocytes, Ras/MAP kinase signals facilitate NFAT-dependent transcription (Crabtree and Olson, 2002). 
My results provide the first report suggesting ERK involvement in NFAT activation in neurons. It suggests that neuronal signaling machinery, which regulates NFAT, is similar to that of lymphocytes and cardiomyocytes, which required both calcineurin and ERK to activate NFAT (Genot et al., 1996).

My data indicate that in cortical neurons NFATc4-mediated transcription is induced by LY294002 treatment. Interestingly, the NFATc4-driven transcription activation triggered by LY294002 required calcineurin and MAPK pathways. It is known that in primary neurons LY294002 blocks the main trophic support signaling pathway by inhibition of PI3K, which in consequence activates GSK3 $\beta$ (Hetman et al., 2000). This activation may inhibit NFATc (Graef et al., 1999). At the moment, it is unclear how NFATc escapes this inhibition in LY-treated neurons. Some possibilities may include: (i) activation of stress-activated JNK pathway by TD (Xia et al., 1995), or (ii) activation of TNF $\propto \mathrm{R}$ by inhibition of PI3K that leads to calcium influx and therefore, calcineurin activation (Wang et al., 2002). It is known that JNK pathway is activated by TD (Xia et al., 1995; Le-Niculescu et al., 1999), which modulates activity of AP-1, leading to induction of FasL and cell death in neurons (Le-Niculescu et al., 1999; Raoul et al., 1999). Activation of AP1 by JNK may counteract the inhibitory regulation of NFAT by GSK3 $\beta$ resulting in activation of NFAT-driven transcription. Another possibility is that TD triggers calcineurin activation that can antagonize increased NFATc phosphorylation by GSK3 $\beta$. Indeed, calcium signaling may be activated by stimuli active during TD. For instance, in colon cancer cells, TNF $\alpha$, which is also a NFAT target gene, activated TNF $\alpha$ R leading to calcium influx (Wang et al., 2002).

The role of NFAT activation by TD or by LY294002 treatment in neurons is unclear. An interesting possibility is that NFAT is involved in TD-triggered cell death. Interestingly, NFAT was shown to play a role in cell death of lymphocytes (Srivastava et al., 1999; Youn et al., 2000). The unpublished data from Dr. Hetman's laboratory 
suggests involvement of NFATc4 in neuronal death (see Fig. 5 in the introduction). For instance, overexpression of NFATc4 wt increased number of apoptotic cells, while inhibition of NFAT by a dominant negative mutant, had no effect on cell death. This result suggests that the active NFATc4 isoform may be a pro-death factor in neurons. Moreover, I found enhancement of cell death in neurons overexpressing NFATc4 after TD. This observation indicates that NFATc4 may be a stress-activated transcription factor, which together with other transcription factors including FOXO, mediates cell death in neurons. NFATc4 may bind to DNA and NFATn components forming a complex like they do in non-neuronal cells to subsequently activate NFAT target genes including killer genes like FasL, Cox2 or TNF $\propto$ that were implicated in neuronal death (Venters et al., 2000a, b; Cernak et al., 2001; Facchinetti et al., 2002; Xiang et al., 2002).

Other transcription factors were also shown to trigger various cellular responses depending on the activating stimulus. In neurons, contribution of NFKB to pro- and anti-apoptotic events has been reported. For instance, TNF $\alpha$ is able to protect primary hippocampal neurons exposed to excitotoxic and apoptotic insults (Cheng et al., 1994; Barger et al., 1995) via NFkB-mediated expression of several anti-apoptotic genes including an antioxidant defense enzyme, manganese superoxide dismutase (MnSOD), and cell death inhibitors Bcl-2, Bcl-xL and IAPs (Dixon et al., 1997; Mattson et al., 2000). Pro-apoptotic role of NFKB has been shown by activation of NMDA receptor by the excitotoxin quinolic acid, which triggers NFkB activation and increase of pro-apoptotic effectors of NFKB activity: p53 and c-myc expression (Qin et al., 1999). NFKB-dependent activation of other killer genes including CD95 was shown during neuronal death caused by ischemia (Schneider et al., 1999).

Other transcription factors also act in similar ways leading either to cell death or survival. AP1 is an example of a transciption factor whose induction results in activation of various genes, such as apoptosis enhancers, FasL or Bim, or apoptosis 
inhibitors including Bcl3 (Shaulian and Karin, 2002). The regulation and function of transcription factors playing dual roles are highly complex. These transcriptions factors are also important regulators of many aspects of the cellular response. Their differential activation can result in the regulation of different target genes through differences in the DNA-binding affinity. Interactions with various DNA-binding proteins, often resulting in cooperative DNA-binding, can determine which genes become activated by transcription factors. Moreover, coactivator and co-repressor complexes are often required for the transcription factors function. Therefore, transcription factors working together and operating as a part of a network of coordinately regulated DNA-binding proteins determine the gene expression required for the response to a particular cellular stimulus (Neil et al., 2004).

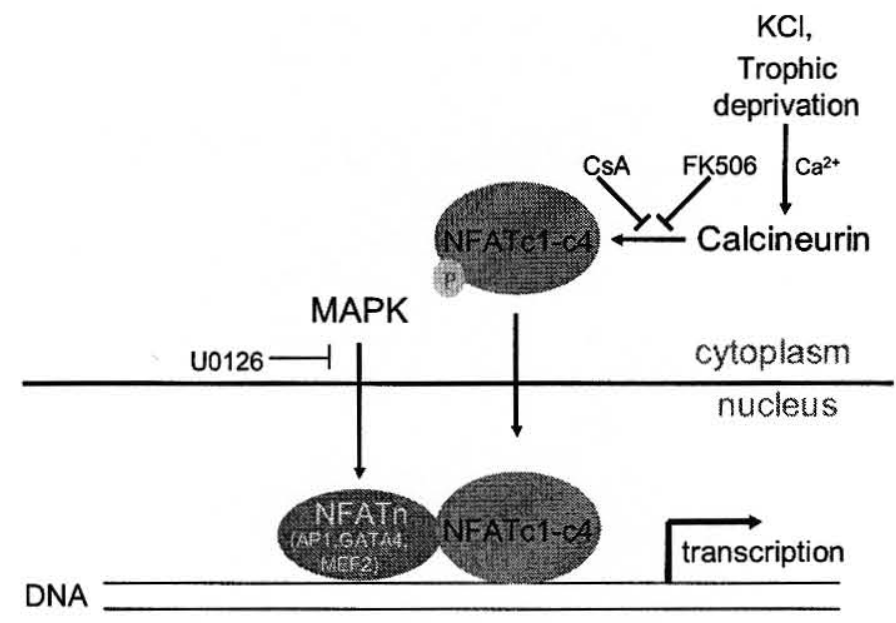

Figure 12. Activation of NFAT in cortical neurons. NFAT is activated by $\mathrm{KCl}$ or TD via calcineurin and MAPK pathways leading to NFAT nuclear translocation where it binds to DNA and its nuclear partners, NFATn incluing AP1, GATA4 or MEF2. Formation of such complex induces activation of transcription.

Similarly, NFAT can play differential roles in neurons. Depending on pro-survival or pro-death stimuli that activated NFAT, it may transactivate distinct sets of genes producing either cell survival or death. It is the balance between pro-apoptotic and anti-apoptotic target genes that will determine whether the final outcome will be cell survival or cell death and that balance may be set at different points for various cell 
types (Shaulian and Karin, 2002). Also, different isoforms of NFAT may be selectively activated by different stimuli to regulate either survival or killer genes. For instance, in lymphocytes, activation of NFATc1 and NFATc2 isoforms leads to cell death (Peng et al., 2001) while activation of NFATc3 plays a pro-survival role (Oukka et al., 1998). Therefore, in neurons, various isoforms of NFAT can have opposite effects on cell survival.

In the work presented here I report that NFAT is expressed in cortical and hippocampal neurons. Furthermore, I found activation of NFAT-mediated transcription by pro-survival $\mathrm{KCl}$ and pro-apoptotic LY294002 treatment. Both stimuli activated NFAT via calcineurin and MAPK pathways. Apoptosis induced by serum deprivation and LY294002 treatment was increased in NFATc4 wt overexpressing neurons suggesting that NFAT may regulate killer genes (Fig. 12). Therefore, these results indicate the importance of NFAT as a transcription factor playing a role in the regulation of a balance between pro-apoptotic and anti-apoptotic target genes. Further studies are needed to identify the role of NFAT signaling in trophic deprived or trophic supported neurons.

\section{Future directions}

It is known that when NFATc is activated, it is translocated to the nucleus where it binds to its nuclear partners and to DNA (Crabtree and Olson, 2002; Neal and Clipstone, 2001). Therefore, I plan to use Electromobility Shift Assay (EMSA) to study DNA binding activity to NFAT-response elements in nuclear proteins isolated from cortical and hippocampal neurons treated with LY294002, serum withdrawal or $\mathrm{KCl}$ (Lyakh et al., 1997). Lysates will be collected at different times after treatment. To identify DNA binding components of NFAT, an Electromobility Supershift Assay (ESA) with specific antibodies against NFAT nuclear partners including AP1, GATA4 and MEF2 will be used. Similarly, antibodies against NFATc family members will 
be used to identify which members are involved in NFAT-mediated transcription. An alternative approach for these methods might be Chromatin Immunoprecipitation assay (ChIP), which can use antibodies to precipitate DNA bound by transcription factors. Moreover, in contradistinction to EMSA, it can be used in vivo, providing a powerful tool to unravel the basic mechanism in gene expression.

Data obtained in our laboratory show that NFATc4 mediates apoptosis in cortical neurons. Therefore, I will study neuroprotective effect after NFAT blocking. I showed that NFAT activation is calcineurin and MAPK pathways-mediated, so I will identify whether calcineurin inhibitors, cyclosporin A and FK506 or MAPK blocker, U0126 protect against TD or LY294002-induced neuronal apoptosis mediated by NFATc4. Because cyclosporin A additionally inhibits the mitochondrial permeability transition pore and is neuroprotective (Scheff and Sullivan, 1999; Santos and Schauwecker, 2003), first I will investigate whether FK506 blocks NFAT activation and translocation alone. Subsequently, I will test whether FK506 blocks neuronal apoptosis. Next, I will verify if NFAT-induced neuronal apoptosis is isoform-specific. I will achieve that by overexpressing neurons with other NFAT wt isoforms in the presence of $\beta$-galactosidase expression plasmid, which will be exposed to TD. I will use pBJ5-NFATc4 delta mutant as an NFAT blocker, because it blocks all other NFAT isoforms. I will use empty vector pBJ5 as a control. After various time points, I will fix cells, then do immunostaining and verify apoptosis in correlation to transfected cells. In addition, lentiviral vectors will be used to transduce neurons with NFAT wt, ca, dominant negative forms or VIVIT (Naldini et al., 1996). Dominant negative mutants of NFATc4 inhibit all members of the NFATc family (NFATc1-4). It is generated by deletion of the C-terminal DNA binding domain and blocks the binding of NFAT to DNA (Chow et al., 1999). VIVIT blocks NFATc1-4 interactions with the phosphatase, calcineurin, which mediates NFATc activation through $\mathrm{Ca}^{2+}$ influx. It is a high-affinity calcineurin-docking peptide, which was selected from combinatorial 
peptide libraries based on the calcineurin-docking motif of NFAT (Aramburu et al., 1999). Lentiviral vectors transduction gives high efficiencies (90\%), so MTT assays will be used for verification of neuronal survival.

I hypothesize that NFAT activation, which is calcineurin and MAPK-mediated can be opposed by p38 or PKA kinases. I plan to test regulation of NFAT by p38 and PKA using MKK3 and/or MKK6 ca mutants to activate p38, forskolin and Sp-cAMP to activate PKA. These tools will be used to test whether activation of p38 and PKA can decrease NFAT-driven transcription in neurons. To assess the possible involvement of p38 or PKA in regulating NFAT-induced apoptosis, I will express NFATc wt and treat cortical or hippocampal neurons with p38 or PKA activators. SB202190 or SB 203580 (p38 inhibitors) and H89 or Rp-cAMP (inhibitors of PKA) will be used to study the contribution of p38 and PKA to NFAT-mediated apoptosis that will be assessed by immuno- and bisbenzimidine staining. If p38 and PKA are involved in regulation of NFATc, their activation should block NFAT nuclear translocation and inhibit neuronal apoptosis. Inhibition of these kinases should abolish the protective effect of p38 or PKA activators. Activation of NFAT leads to transcriptional activaton of various genes including FasL, TNFa and Cox2, which are implicated in neuronal death (Humar et al., 2004; Cernak et al., 2001; Venters et al., 2000a; 2000b; Xiang et al., 2002). Therefore, I plan to evaluate possible involvement of FasL, Cox2 and $\mathrm{TNF} \alpha$ in NFAT-induced neuronal death. In order to study expression of these factors, protein lysates will be collected from neurons treated with LY294002 or trophic withdrawal and westerns will be performed. If expression of these proteins increases after NFAT activation, TNF $\alpha$ and FasL receptors and Cox 2 will be blocked to assess whether they may contribute to NFAT-mediated neuronal death.

This project may result in novel neuroprotective strategies in neuronal diseases like traumatic brain injury, spinal cord injury, Alzheimer's disease, Parkinson's disease, Huntington's disease, stroke or ischemia. 


\section{REFERENCES}

Alberts B, Johnson A, Lewis J, Raff M, Roberts K, Walter P (2002) Molecular Biology of The Cell.

Ankarcrona M, Dypbukt JM, Bonfoco E, Zhivotovsky B, Orrenius S, Lipton SA, Nicotera P (1995) Glutamate-induced neuronal death: a succession of necrosis or apoptosis depending on mitochondrial function. Neuron 15:961-973.

Aramburu J, Yaffe MB, Lopez-Rodriguez C, Cantley LC, Hogan PG, Rao A (1999) Affinity-driven peptide selection of an NFAT inhibitor more selective than cyclosporin A. Science 285:2129-2133.

Azbill RD, Mu X, Bruce-Keller AJ, Mattson MP, Springer JE (1997) Impaired mitochondrial function, oxidative stress and altered antioxidant enzyme activities following traumatic spinal cord injury. Brain Res 765:283-290.

Bading H, Greenberg ME (1991) Stimulation of protein tyrosine phosphorylation by NMDA receptor activation. Science 253:912-914.

Barger SW, Horster D, Furukawa K, Goodman Y, Krieglstein J, Mattson MP (1995) Tumor necrosis factors alpha and beta protect neurons against amyloid betapeptide toxicity: evidence for involvement of a kappa B-binding factor and attenuation of peroxide and Ca2+ accumulation. Proc Natl Acad Sci U S A 92:9328-9332.

Beals CR, Sheridan CM, Turck CW, Gardner P, Crabtree GR (1997) Nuclear export of NF-ATc enhanced by glycogen synthase kinase-3. Science 275:1930-1934.

Bhave SV, Ghoda L, Hoffman PL (1999) - Brain-derived neurotrophic factor mediates the anti-apoptotic effect of NMDA in cerebellar granule neurons: signal transduction cascades and site of ethanol action. J Neurosci 19:3277-3286.

Borodinsky LN, Fiszman ML (1998) Extracellular potassium concentration regulates proliferation of immature cerebellar granule cells. Brain Res Dev Brain Res 107:43-48. 
Brunet A, Datta SR, Greenberg ME (2001) Transcription-dependent and independent control of neuronal survival by the PI3K-Akt signaling pathway. Curr Opin Neurobiol 11:297-305.

Bushdid PB, Osinska H, Waclaw RR, Molkentin JD, Yutzey KE (2003) NFATc3 and NFATc4 are required for cardiac development and mitochondrial function. Circ Res 92:1305-1313. Epub 2003 May 1315.

Cernak I, O'Connor C, Vink R (2001) Activation of cyclo-oxygenase-2 contributes to motor and cognitive dysfunction following diffuse traumatic brain injury in rats. Clin Exp Pharmacol Physiol 28:922-925.

Cheng B, Christakos S, Mattson MP (1994) Tumor necrosis factors protect neurons against metabolic-excitotoxic insults and promote maintenance of calcium homeostasis. Neuron 12:139-153.

Choi DW (1996) Ischemia-induced neuronal apoptosis. Curr Opin Neurobiol 6:667672 .

Cortes-Canteli M, Pignatelli M, Santos A, Perez-Castillo A (2002) CCAAT/enhancerbinding protein beta plays a regulatory role in differentiation and apoptosis of neuroblastoma cells. J Biol Chem 277:5460-5467. Epub 2001 Dec 5463.

Chow CW, Rincon M, Cavanagh J, Dickens M, Davis RJ (1997) Nuclear accumulation of NFAT4 opposed by the JNK signal transduction pathway. Science 278:16381641.

Crabtree GR, Olson EN (2002) NFAT signaling: choreographing the social lives of cells. Cell 109:S67-79.

Crossthwaite AJ, Hasan S, Williams RJ (2002) Hydrogen peroxide-mediated phosphorylation of ERK1/2, Akt/PKB and JNK in cortical neurones: dependence on $\mathrm{Ca}(2+)$ and PI3-kinase. J Neurochem 80:24-35.

Dixon EP, Stephenson DT, Clemens JA, Little SP (1997) Bcl-Xshort is elevated following severe global ischemia in rat brains. Brain Res 776:222-229.

Ekshyyan O, Aw TY (2004) Apoptosis in acute and chronic neurological disorders. Front Biosci 9:1567-1576.

Facchinetti F, Furegato S, Terrazzino S, Leon A (2002) H(2)O(2) induces upregulation of Fas and Fas ligand expression in NGF-differentiated PC12 cells: modulation by cAMP. J Neurosci Res 69:178-188. 
Furshpan EJ, Potter DD (1989) Seizure-like activity and cellular damage in rat hippocampal neurons in cell culture. Neuron 3:199-207.

Genot E, Cleverley S, Henning S, Cantrell D (1996) Multiple p21ras effector pathways regulate nuclear factor of activated T cells. Embo J 15:3923-3933.

Ghatan S, Larner S, Kinoshita Y, Hetman M, Patel L, Xia Z, Youle RJ, Morrison RS (2000) p38 MAP kinase mediates bax translocation in nitric oxide-induced apoptosis in neurons. J Cell Biol 150:335-347.

Ghosh A, Greenberg ME (1995) Calcium signaling in neurons: molecular mechanisms and cellular consequences. Science 268:239-247.

Gill JS, Windebank AJ (1998) Cisplatin-induced apoptosis in rat dorsal root ganglion neurons is associated with attempted entry into the cell cycle. J Clin Invest 101:2842-2850.

Gilley J, Coffer PJ, Ham J (2003) FOXO transcription factors directly activate bim gene expression and promote apoptosis in sympathetic neurons. J Cell Biol 162:613-622. Epub 2003 Aug 2011.

Gomez del Arco P, Martinez-Martinez S, Maldonado JL, Ortega-Perez I, Redondo JM (2000) A role for the p38 MAP kinase pathway in the nuclear shuttling of NFATp. J Biol Chem 275:13872-13878.

Graef IA, Chen F, Crabtree GR (2001) NFAT signaling in vertebrate development. Curr Opin Genet Dev 11:505-512.

Graef IA, Mermelstein PG, Stankunas K, Neilson JR, Deisseroth K, Tsien RW, Crabtree GR (1999) L-type calcium channels and GSK-3 regulate the activity of NFATc4 in hippocampal neurons. Nature 401:703-708.

Graef IA, Wang F, Charron F, Chen L, Neilson J, Tessier-Lavigne M, Crabtree GR (2003) Neurotrophins and netrins require calcineurin/NFAT signaling to stimulate outgrowth of embryonic axons. Cell 113:657-670.

Green DR, Reed JC (1998) Mitochondria and apoptosis. Science 281:1309-1312.

Groth RD, Mermelstein PG (2003) Brain-derived neurotrophic factor activation of NFAT (nuclear factor of activated T-cells)-dependent transcription: a role for the transcription factor NFATc4 in neurotrophin-mediated gene expression. J Neurosci 23:8125-8134. 
Habas A, Gozdz A, Hetman M (2001) Apoptosis as a causitive factor and a therapeutic opportunity in pathologies. Annals of Diagnostic Paediatric Pathology 5:19-25.

Halterman MW, Federoff HJ (1999) HIF-1alpha and p53 promote hypoxia-induced delayed neuronal death in models of CNS ischemia. Exp Neurol 159:65-72.

Harada H, Grant S (2003) Apoptosis regulators. Rev Clin Exp Hematol 7:117-138.

Hetman M, Kanning K, Smith-Cavanaugh JE, Xia Z (1999) Neuroprotection by Brain-Derived Neurotrophic Factor Is Mediated by Extracellular-SignalRegulated Kinase and Phosphatidylinositol-3 Kinase. J Biol Chem 274:2256922580 .

Hetman M, Xia Z (2000) Signaling pathways mediating anti-apoptotic action of neurotrophins. Acta Neurobiol Exp 60:531-545.

Hetman M, Hsuan SL, Habas A, Higgins MJ, Xia Z (2002) ERK1/2 Antagonizes Glycogen Synthase Kinase-3beta -induced Apoptosis in Cortical Neurons. J Biol Chem 277:49577-49584.

Hogan PG, Chen L, Nardone J, Rao A (2003) Transcriptional regulation by calcium, calcineurin, and NFAT. Genes Dev 17:2205-2232.

Hongisto V, Smeds N, Brecht S, Herdegen T, Courtney MJ, Coffey ET (2003) Lithium blocks the c-Jun stress response and protects neurons via its action on glycogen synthase kinase 3. Mol Cell Biol 23:6027-6036.

Horton JK, Prasad R, Hou E, Wilson SH (2000) Protection against methylationinduced cytotoxicity by DNA polymerase beta-dependent long patch base excision repair. J Biol Chem 275:2211-2218.

Hugon J, Terro F, Esclaire F, Yardin C (2000) Markers of apoptosis and models of programmed cell death in Alzheimer's disease. J Neural Transm Suppl 59:125131.

Humar M, Pischke SE, Loop T, Hoetzel A, Schmidt R, Klaas C, Pahl HL, Geiger KK, Pannen BH (2004) Barbiturates directly inhibit the calmodulin/calcineurin complex: a novel mechanism of inhibition of nuclear factor of activated $\mathrm{T}$ cells. Mol Pharmacol 65:350-361.

Hutchins JB, Barger SW (1998) Why neurons die: cell death in the nervous system. Anat Rec 253:79-90. 
Jones EA, Sun D, Kobierski L, Symes AJ (2003) NFAT4 is expressed in primary astrocytes and activated by glutamate. J Neurosci Res 72:191-197.

Kanduc D, Mittelman A, Serpico R, Sinigaglia E, Sinha AA, Natale C, Santacroce R, Di Corcia MG, Lucchese A, Dini L, Pani P, Santacroce S, Simone S, Bucci R, Farber E (2002) Cell death: apoptosis versus necrosis (review). Int J Oncol 21:165-170.

Keller JN, Hanni KB, Markesbery WR (1999) 4-hydroxynonenal increases neuronal susceptibility to oxidative stress. J Neurosci Res 58:823-830.

Kiani A, Rao A, Aramburu J (2000) Manipulating immune responses with immunosuppressive agents that target NFAT. Immunity 12:359-372.

Krammer PH (2000) CD95's deadly mission in the immune system. Nature 407:789795.

Le-Niculescu H, Bonfoco E, Kasuya Y, Claret FX, Green DR, Karin M (1999) Withdrawal of survival factors results in activation of the JNK pathway in neuronal cells leading to Fas ligand induction and cell death. Mol Cell Biol 19:751-763.

Lenzlinger PM, Marx A, Trentz O, Kossmann T, Morganti-Kossmann MC (2002) Prolonged intrathecal release of soluble Fas following severe traumatic brain injury in humans. J Neuroimmunol 122:167-174.

Lewen A, Sugawara T, Gasche Y, Fujimura M, Chan PH (2001) Oxidative cellular damage and the reduction of APE/Ref-1 expression after experimental traumatic brain injury. Neurobiol Dis 8:380-390.

Li H, Yuan J (1999) Deciphering the pathways of life and death. Curr Opin Cell Biol 11:261-266. Li L, Oppenheim RW, Milligan CE (2001) Characterization of the execution pathway of developing motoneurons deprived of trophic support. J Neurobiol 46:249-264.

Liang Q, Wiese RJ, Bueno OF, Dai YS, Markham BE, Molkentin JD (2001) The transcription factor GATA4 is activated by extracellular signal-regulated kinase 1- and 2-mediated phosphorylation of serine 105 in cardiomyocytes. Mol Cell Biol 21:7460-7469.

Lipton SA (1999) Neuronal protection and destruction by NO. Cell Death Differ 6:943-951. 
Liu PK (2001) DNA damage and repair in the brain after cerebral ischemia. Curr Top Med Chem 1:483-495.

Lopez-Rodriguez C, Aramburu J, Rakeman AS, Rao A (1999) NFAT5, a constitutively nuclear NFAT protein that does not cooperate with Fos and Jun. Pro Natl Acad Sci USA 96:7214-7219.

Lyakh L, Ghosh P, Rice NR (1997) Expression of NFAT-family proteins in normal human T cells. Mol Cell Biol 17:2475-2484.

Macian F, Lopez-Rodriguez C, Rao A (2001) Partners in transcription: NFAT and AP-1. Oncogene 20:2476-2489.

Manev H, Cagnoli CM, Atabay C, Kharlamov E, Ikonomovic MD, Grayson DR (1995) Neuronal apoptosis in an in vitro model of photochemically induced oxidative stress. Exp Neurol 133:198-206.

Marshall J, Dolan BM, Garcia EP, Sathe S, Tang X, Mao Z, Blair LA (2003) Calcium channel and NMDA receptor activities differentially regulate nuclear $\mathrm{C} / \mathrm{EBP}$ beta levels to control neuronal survival. Neuron 39:625-639.

Martin LJ, Price AC, McClendon KB, Al-Abdulla NA, Subramaniam JR, Wong PC, Liu Z (2003) Early events of target deprivation/axotomy-induced neuronal apoptosis in vivo: oxidative stress, DNA damage, p53 phosphorylation and subcellular redistribution of death proteins. J Neurochem 85:234-247.

Mason RP, Leeds PR, Jacob RF, Hough CJ, Zhang KG, Mason PE, Chuang DM (1999) Inhibition of excessive neuronal apoptosis by the calcium antagonist amlodipine and antioxidants in cerebellar granule cells. J Neurochem 72:1448-1456.

Masuda ES, Imamura R, Amasaki Y, Arai K, Arai N (1998) Signalling into the T-cell nucleus: NFAT regulation. Cell Signal 10:599-611.

Mattson MP, Culmsee C, Yu Z, Camandola S (2000) Roles of nuclear factor kappaB in neuronal survival and plasticity. J Neurochem 74:443-456.

Mattson MP (2003) Methylation and acetylation in nervous system development and neurodegenerative disorders. Ageing Res Rev 2:329-342.

McIntosh TK, Saatman KE, Raghupathi R, Graham DI, Smith DH, Lee VM, Trojanowski JQ (1998) The Dorothy Russell Memorial Lecture. The molecular and cellular sequelae of experimental traumatic brain injury: pathogenetic mechanisms. Neuropathol Appl Neurobiol 24:251-267. 
Modur V, Nagarajan R, Evers BM, Milbrandt J (2002) FOXO proteins regulate tumor necrosis factor-related apoptosis inducing ligand expression. Implications for PTEN mutation in prostate cancer. J Biol Chem 277:47928-47937. Epub 42002 Sep 47925.

Morrison RS, Kinoshita Y (2000) The role of p53 in neuronal cell death. Cell Death Differ 7:868-879.

Muramoto M, Yamazaki T, Nishimura S, Kita Y (2003) Detailed in vitro pharmacological analysis of FK506-induced neuroprotection. Neuropharmacology 45:394403.

Murphy LL, Hughes CC (2002) Endothelial cells stimulate T cell NFAT nuclear translocation in the presence of cyclosporin A: involvement of the wnt/glycogen synthase kinase-3 beta pathway. J Immunol 169:3717-3725.

Nagane M, Pan G, Weddle JJ, Dixit VM, Cavenee WK, Huang HJ (2000) Increased death receptor 5 expression by chemotherapeutic agents in human gliomas causes synergistic cytotoxicity with tumor necrosis factor-related apoptosis-inducing ligand in vitro and in vivo. Cancer Res 60:847-853.

Naldini L, Blomer U, Gage FH, Trono D, Verma IM (1996) Efficient transfer, integration, and sustained long-term expression of the transgene in adult rat brains injected with a lentiviral vector. Proc Natl Acad Sci U S A 93:11382-11388.

Neal JW, Clipstone NA (2003) A constitutively active NFATc1 mutant induces a transformed phenotype in 3T3-L1 fibroblasts. J Biol Chem 278:17246-17254.

Okamura H, Aramburu J, Garcia-Rodriguez C, Viola JP, Raghavan A, Tahiliani M, Zhang X, Qin J, Hogan PG, Rao A (2000) Concerted dephosphorylation of the transcription factor NFAT1 induces a conformational switch that regulates transcriptional activity. Mol Cell 6:539-550.

Orrenius S, Nicotera P (1994) The calcium ion and cell death. J Neural Transm Suppl 43:1-11.

Oukka M, Ho IC, de la Brousse FC, Hoey T, Grusby MJ, Glimcher LH (1998) The transcription factor NFAT4 is involved in the generation and survival of $\mathrm{T}$ cells. Immunity 9:295-304. 
Park JH, Levitt L (1993) Overexpression of mitogen-activated protein kinase (ERK1) enhances T-cell cytokine gene expression: role of AP1, NF-AT, and NF-KB. Blood 82:2470-2477.

Peng SL, Gerth AJ, Ranger AM, Glimcher LH (2001) NFATc1 and NFATc2 together control both $\mathrm{T}$ and $\mathrm{B}$ cell activation and differentiation. Immunity 14:13-20.

Petersen A, Mani K, Brundin P (1999) Recent advances on the pathogenesis of Huntington's disease. Exp Neurol 157:1-18.

Pittman RN, Wang S, DiBenedetto AJ, Mills JC (1993) A system for characterizing cellular and molecular events in programmed neuronal cell death. J Neurosci 13:3669-3680.

Polster BM, Fiskum G (2004) Mitochondrial mechanisms of neural cell apoptosis. J Neurochem 90:1281-1289.

Porter CM, Havens MA, Clipstone NA (2000) Identification of amino acid residues and protein kinases involved in the regulation of NFATc subcellular localization. J Biol Chem 275:3543-3551.

Pu WT, Ma Q, Izumo S (2003) NFAT transcription factors are critical survival factors that inhibit cardiomyocyte apoptosis during phenylephrine stimulation in vitro. Circ Res 92:725-731. Epub 2003 Mar 2027.

Putcha GV, Johnson EM, Jr. (2004) Men are but worms: neuronal cell death in C elegans and vertebrates. Cell Death Differ 11:38-48.

Qin ZH, Chen RW, Wang Y, Nakai M, Chuang DM, Chase TN (1999) Nuclear factor kappaB nuclear translocation upregulates c-Myc and p53 expression during NMDA receptor-mediated apoptosis in rat striatum. J Neurosci 19:4023-4033.

Raff MC, Barres BA, Burne J, Coles HS, Ishizaki Y, Jacobson MD (1993) Programmed cell death and the control of cell survival: lessons from the nervous system. Science 262:695-700.

Raoul C, Henderson CE, Pettmann B (1999) Programmed cell death of embryonic motoneurons triggered through the Fas death receptor. J Cell Biol 147:1049-1062.

Robertson JD, Orrenius S (2000) Molecular mechanisms of apoptosis induced by cytotoxic chemicals. Crit Rev Toxicol 30:609-627. 
Rosen LB, Ginty DD, Weber MJ, Greenberg ME (1994) Membrane depolarization and calcium influx stimulate MEK and MAP kinase via activation of ras. Neuron 12:1207-1221.

Sarder M, Saito H, Abe K (1993) Interleukin-2 promotes survival and neurite extension of cultured neurons from fetal rat brain. Brain Res 625:347-350.

Sastry PS, Rao KS (2000) Apoptosis and the nervous system. J Neurochem 74:1-20.

Schneider A, Martin-Villalba A, Weih F, Vogel J, Wirth T, Schwaninger M (1999) NF-kappaB is activated and promotes cell death in focal cerebral ischemia. Nat Med 5:554-559.

Schubert W, Yang XY, Yang TT, Factor SM, Lisanti MP, Molkentin JD, Rincon M, Chow CW (2003) Requirement of transcription factor NFAT in developing atrial myocardium. J Cell Biol 161:861-874.

Shaulian E, Karin M (2002) AP-1 as a regulator of cell life and death. Nat Cell Biol 4:E131-136.

Sheridan CM, Heist EK, Beals CR, Crabtree GR, Gardner P (2002) Protein kinase A negatively modulates the nuclear accumulation of NF-ATc1 by priming for subsequent phosphorylation by glycogen synthase kinase-3. J Biol Chem 277:4866448676.

Sholl-Franco A, Figueiredo KG, de Araujo EG (2001) Interleukin-2 and interleukin-4 increase the survival of retinal ganglion cells in culture. Neuroreport 12:109-112.

Simonian NA, Coyle JT (1996) Oxidative stress in neurodegenerative diseases. AnnuRev-Pharmacol-Toxicol 36:83-106.

Srivastava RK, Sasaki CY, Hardwick JM, Longo DL (1999) Bcl-2-mediated drug resistance: inhibition of apoptosis by blocking nuclear factor of activated $\mathrm{T}$ lymphocytes (NFAT)-induced Fas ligand transcription. J Exp Med 190:253-265.

Suh Y (2002) Cell signaling in aging and apoptosis. Mech Ageing Dev 123:881-890.

Takeda K, Ichijo H (2002) Neuronal p38 MAPK signalling: an emerging regulator of cell fate and function in the nervous system. Genes Cells 7:1099-1111. 
Tamatani M, Mitsuda N, Matsuzaki H, Okado H, Miyake S, Vitek MP, Yamaguchi A, Tohyama M (2000) A pathway of neuronal apoptosis induced by hypoxia/reoxygenation: roles of nuclear factor-kappaB and Bcl-2. J Neurochem 75:683-693.

Thornberry NA, Lazebnik Y (1998) Caspases: enemies within. Science 281:1312-1316.

Tsujimoto Y, Shimizu S (2000) Bcl-2 family: life-or-death switch. FEBS Lett 466:610.

Uings IJ, Farrow SN (2000) Cell receptors and cell signalling. Mol Pathol 53:295-299.

Vajda FJ (2002) Neuroprotection and neurodegenerative disease. J Clin Neurosci 9:4-8.

Vaux DL (1993) Toward an understanding of the molecular mechanisms of physiological cell death. [Review]. Proc Natl Acad Sci U S A 90:786-789.

Venters HD, Dantzer R, Kelley KW (2000) A new concept in neurodegeneration: TNFalpha is a silencer of survival signals. Trends Neurosci 23:175-180.

Venters HD, Dantzer R, Kelley KW (2000a) Tumor necrosis factor-alpha induces neuronal death by silencing survival signals generated by the type I insulin-like growth factor receptor. Ann N Y Acad Sci 917:210-220.

Vink R, Nimmo AJ, Cernak I (2001) An overview of new and novel pharmacotherapies for use in traumatic brain injury. Clin Exp Pharmacol Physiol 28:919-921.

Viola JP, Kiani A, Bozza PT, Rao A (1998) Regulation of allergic inflammation and eosinophil recruitment in mice lacking the transcription factor NFAT1: role of interleukin-4 (IL-4) and IL-5. Blood 91:2223-2230.

Wajant $H$ (2004) TRAIL and NFkappaB signaling-a complex relationship. Vitam Horm 67:101-132.

Wang Q, Wang X, Hernandez A, Hellmich MR, Gatalica Z, Evers BM (2002) Regulation of TRAIL expression by the phosphatidylinositol 3-kinase/Akt/GSK-3 pathway in human colon cancer cells. J Biol Chem 277:36602-36610. Epub 32002 Jul 36624 .

Whittemore ER, Loo DT, Cotman CW (1994) Exposure to hydrogen peroxide induces cell death via apoptosis in cultured rat cortical neurons. Neuroreport 5:14851488. 
Wood W, Turmaine M, Weber R, Camp V, Maki RA, McKercher SR, Martin P (2000) Mesenchymal cells engulf and clear apoptotic footplate cells in macrophageless PU.1 null mouse embryos. Development 127:5245-5252.

Wu CC, Hsu SC, Shih HM, Lai MZ (2003) Nuclear factor of activated T cells c is a target of p38 mitogen-activated protein kinase in T cells. Mol Cell Biol 23:64426454 .

Xia Z, Dickens M, Raingeaud J, Davis RJ, Greenberg ME (1995) Opposing effects of ERK and JNK-p38 MAP kinases on apoptosis. Science 270:1326-1331.

Xiang Z, Ho L, Valdellon J, Borchelt D, Kelley K, Spielman L, Aisen PS, Pasinetti GM (2002) Cyclooxygenase (COX)-2 and cell cycle activity in a transgenic mouse model of Alzheimer's disease neuropathology. Neurobiol Aging 23:327-334.

Yakes FM, Van Houten B (1997) Mitochondrial DNA damage is more extensive and persists longer than nuclear DNA damage in human cells following oxidative stress. Proc Natl Acad Sci U S A 94:514-519.

Yoshimoto T, Siesjo BK (1999) Posttreatment with the immunosuppressant cyclosporin A in transient focal ischemia. Brain Res 839:283-291.

Youn HD, Chatila TA, Liu JO (2000) Integration of calcineurin and MEF2 signals by the coactivator p300 during T-cell apoptosis. Embo J 19:4323-4331.

Yuan J, Lipinski M, Degterev A (2003) Diversity in the mechanisms of neuronal cell death. Neuron 40:401-413. 


\section{ABBREVIATIONS}

$\mathrm{AD}$

ALS

AraC

BCS

$\mathrm{BME}$

$\beta$-gal

$\mathrm{CaN}$

CD40L

C/EBPs

ChIP

CNS

Cox-2

CPDD

CPT

CTLA-4

CsA

DIV

DMSO

$\mathrm{dn}$

EGFP

EMSA

ESA

FasL
Alzheimer's disease

amyotrophic lateral sclerosis

cytosine arabinoside

bovine calf serum

basal medium eagle

$\beta$-galactosidase

calcineurin

CD40 ligand

CCAAT enhancer binding proteins

chromatin immunoprecipitation assay

central nervous system

cyclooxygenase-2

cisplatin

camptothecin

cytotoxic T-lymphocyte-associated protein 4

cyclosporin A

days in vitro

dimethyl sulfoxide

dominant negative

enhanced green fluorescent protein

electromobility shift assay

electromobility supershift assay

Fas ligand 
FK

FOXO

GFAP

GM-CSF

GSK-3 $\beta$

HA

HD

HIF

HNE

IFN $\gamma$

Ig $G$

IL

IP3R1

JNK

LB

LY

MAP-2

MAPK

MEF-2

MMS

NES

NFAT

NFATn

NFKB

NGF

NLS

NMDA
FK506

forkhead box transcription factor

glial fibrillary acidic protein

granulocyte-macrophage colony-stimulating factor

glycogen synthase kinase- $3 \beta$

hemaglutinin

huntingtin disease

hypoxia inducible factor

4-hydroxynonenal

interferon $\gamma$

immunoglobulin G

interleukin

inositol 1, 4, 5-triphoshate receptor, type 1

jun $\mathrm{N}$-terminal kinase

lysis buffer

LY294002

microtubule associated protein 2

mitogen activated protein kinase

myocyte enhancer factor-2

methyl methanesulfonate

nuclear export sequence

nuclear factors of activated T-cells

nuclear partners of NFAT

nuclear factor $\mathrm{kB}$

nerve growth factor

nuclear localization sequences

$\mathrm{N}$-methyl D-aspartate 
PBS

PBST

PCD

PCR

PD

PI3K

PKA

PKC

ROS

RT-PCR

SCI

SNP

TBI

TBST

TD

Thr/Tyr

TNF $\alpha$

TNFR1

TonEBP

TRAL

wt phosphate buffered saline

PBS with triton-X 100

programmed cell death

polymerase chain reaction

Parkinson's disease

phosphatidylinositol-3 kinase

cAMP-dependent protein kinase

protein kinase $\mathrm{C}$

reactive oxygen species

reverse transcriptase-PCR

spinal cord injury

sodium nitroprusside

traumatic brain injury

tris buffered saline with tween

trophic deprivation

threonin/tyrosine

tumor necrosis factor $\alpha$

receptor 1 of tumor necrosis factor

tonicity element binding protein

TNF-related apoptosis inducing ligands

wild type 


\title{
CURRICULUM VITAE
}

\author{
date of birth: April 1st, 1976 \\ e-mail: agata.habas@louisville.edu
}

$\begin{array}{ll} & \text { EDUCATION } \\ 2003 \text { - present } & \text { Graduate student }\end{array}$

Department of Pharmacology and Toxicology,

University of Louisville, $\mathrm{KY}$

Mentor: Michal Hetman, PhD MD

July - September 2000 Visiting Student, FEBS Summer Fellowship Program Department of Biochemistry, Tel Aviv University, Israel 1996 - 2001 Master of Science in Biotechnology

Agricultural University, Warsaw, Poland specialisation: Biotechnology in production and animals health protection.

\section{WORK EXPERIENCE}

2001 - 2003 Research Associate

International Institute of Molecular and Cell Biology,

Warsaw, Poland

1999 - 2001 Graduate Research Assistant

Nencki Institute of Experimental Biology, Warsaw, Poland 